\title{
The Role of Liquid Biopsy in Early Diagnosis of Lung Cancer
}

\begin{abstract}
Cláudia Freitas ${ }^{1,2 *}$, Catarina Sousa ${ }^{1}$, Francisco Machado ${ }^{1}$, Mariana Serino ${ }^{1}$, Vanessa Santos $^{1}$, Natália Cruz-Martins s,3,4, Armando Teixeira ${ }^{5,6}$, António Cunha ${ }^{7,8}$, Tania Pereira ${ }^{7}$, Hélder P. Oliveira ${ }^{7,9}$, José Luís Costa ${ }^{2,4,10}$ and Venceslau Hespanhol ${ }^{1,2,10}$

${ }^{1}$ Department of Pulmonology, Centro Hospitalar e Universitário São João, Porto, Portugal, 2 Faculty of Medicine, University of Porto, Porto, Portugal, ${ }^{3}$ Laboratory of Neuropsychophysiology, Faculty of Psychology and Education Sciences, University of Porto, Porto, Portugal, ${ }^{4}$ Institute for Research and Innovation in Health (i3S). University of Porto, Porto, Portugal, ${ }^{5}$ Institute for Biomedical Sciences Abel Salazar (ICBAS), University of Porto, Porto, Portugal, ${ }^{6}$ Faculty of Engineering, University of Porto, Porto, Portugal, ${ }^{7}$ Institute for Systems and Computer Engineering, Technology and Science (INESC TEC), Porto, Portugal, ${ }^{8}$ Department of Engineering, University of Trás-os-Montes and Alto Douro, Vila Real, Portugal, ${ }^{9}$ Faculty of Sciences, University of Porto, Porto, Portugal, 10 Institute of Molecular Pathology and Immunology of the University of Porto (IPATIMUP), Porto, Portugal
\end{abstract}

OPEN ACCESS

Edited by:

Rui P.L. Neves,

University Hospital Düsseldorf,

Germany

Reviewed by:

Ella W. Englander,

University of Texas Medical Branch at

Galveston, United States

Menno Tamminga,

University Medical Center Groningen,

Netherlands

*Correspondence:

Cláudia Freitas

claudiaasfreitas@gmail.com

Specialty section:

This article was submitted to

Cancer Molecular

Targets and Therapeutics,

a section of the journal

Frontiers in Oncology

Received: 27 November 2020 Accepted: 19 March 2021

Published: 16 April 2021

Citation:

Freitas C, Sousa C, Machado F, Serino M, Santos V, Cruz-Martins N,

Teixeira A, Cunha A, Pereira T,

Oliveira HP, Costa JL and HespanholV (2021) The Role of Liquid Biopsy in

Early Diagnosis of Lung Cancer.

Front. Oncol. 11:634316.

doi: 10.3389/fonc.2021.634316
Liquid biopsy is an emerging technology with a potential role in the screening and early detection of lung cancer. Several liquid biopsy-derived biomarkers have been identified and are currently under ongoing investigation. In this article, we review the available data on the use of circulating biomarkers for the early detection of lung cancer, focusing on the circulating tumor cells, circulating cell-free DNA, circulating micro-RNAs, tumor-derived exosomes, and tumor-educated platelets, providing an overview of future potential applicability in the clinical practice. While several biomarkers have shown exciting results, diagnostic performance and clinical applicability is still limited. The combination of different biomarkers, as well as their combination with other diagnostic tools show great promise, although further research is still required to define and validate the role of liquid biopsies in clinical practice.

Keywords: lung cancer, clinical biomarkers detection, liquid biopsy, cell-free DNA, exosomes, tumor-educated platelets, circulating tumor associated cells

\section{INTRODUCTION}

Lung cancer (LC) is the most common type of cancer and the leading cause of cancer-related mortality worldwide (1). The prognosis is closely related to the stage at diagnosis, with most cases being diagnosed at locally advanced and advanced stages, when curative treatment is no longer possible $(2,3)$. Thus, to achieve the LC curative treatment, improving overall survival and to diminish the healthcare costs and adverse events related to systemic therapies, the development of novel diagnostic methods that improve the early diagnosis accuracy are of huge importance. Liquid biopsy is a non-invasive, easy and accessible tool for tumor cells or tumor-derived products detection in body fluids, with the potential of overcome the limitations of the strategies currently used for LC early detection. Indeed, the molecular assessment of tumor-derived components from peripheral blood is of high clinical value, besides to represent promising clinical biomarkers (4). In this sense, and given the above highlighted aspects, this review provides an overview on the utility of liquid biopsy components as early diagnostic biomarkers. 


\section{LIQUID BIOPSY IN EARLY DIAGNOSIS: WHAT IS THE RATIONALE?}

Thoracic imaging is the traditional method used for early detection of LC, that occur either as an incidental finding or integrated in a screening program. The National Lung Screening Trial (NLST) showed a reduction of $20 \%$ in LC specific mortality rate with chest low dose computed tomography (LDCT) screening among high risk individuals, when compared with chest X-ray (5). Recently, the same trial with a median follow-up of 12 years confirmed consistent benefits in terms of LC-related deaths reduction (6). However, the rate of false positives, overdiagnosis and unnecessary invasive procedures still remain major concerns (7).

Tissue biopsies are essential for LC diagnosis. Despite imaging-guided percutaneous needle biopsy has been considered as a relatively safe procedure for peripheral lesions diagnosis, it is not free of complications $(8,9)$. Bronchoscopy has also a pivotal role in LC diagnosis, with flexible bronchoscopy being the more useful test for central lesions, whereas navigational bronchoscopy and radial endobronchial ultrasound (EBUS) display higher sensitivities for peripheral lesions (10). Nonetheless, although uncommon, complications may occur (11). Tissue biopsies, although of extreme interest and usefulness, have also limitations. For instance, due to tumor heterogeneity, a single biopsy may not be representative of the entire tumor and may misjudge the complexity of its genetic aberrations (12). Also, the primary tumor and its metastases may have significant inter- and even intra-tumor heterogeneity (12). Thus, the lack of enough tissue sample to carry out a complete tumor characterization, comprising histology, immunohistochemistry and genetic analysis, essential for therapeutic decision and prognosis definition, often represents an issue in clinical practice. Although transthoracic needle aspiration or biopsies perform better than bronchoscopic procedures in peripherical lung lesions diagnosis, this technique only provides the confirmation of diagnosis in $90 \%$ of LC cases, with $20-30 \%$ false negatives (10).

More recently, other strategies have been explored, with circulating biomarkers being target of an extreme attention and interest. Briefly, biomarker is defined as a feature that can be objectively measured and evaluated as an indicator of biological and pathogenic processes, or pharmacologic responses to therapeutic intervention (13). Circulating or other body fluid, especially respiratory samples biomarkers may be viewed as key strategies for improving LC early diagnosis. In this way, liquid biopsy, as a non-invasive, safe and easy procedure, has the potential to improve the currently used strategies for LC diagnosis, either in screening setting or as an alternative diagnostic tool, either alone or as complementary data for imaging findings. Several clinical applications have been reported in LC, including patients stratification, therapeutic decision, and disease monitoring either after surgery or during systemic therapies, enabling to detect the acquired resistance (14). Although the role of liquid biopsy in LC early detection is not yet defined, there is increasing evidence about its potential applications.

\section{THE BIOLOGY BEHIND LIQUID BIOPSIES}

Circulating tumor cells (CTCs) and circulating cell-free DNA (cfDNA) are the most studied liquid biopsy-derived biomarkers, but many others have also been investigated (15) (Figure 1). Table 1 summarizes their advantages and limitations.

\section{Circulating Cell-Free DNA}

Tumor cells release DNA fragments into the bloodstream or other anatomic-related body fluid, such as urine or pleural fluid. It is known that cancer patients have higher levels of cfDNA than healthy individuals and, since the tumor volume correlates with cell turnover and death, circulating tumor DNA (ctDNA) concentration increases with tumor size $(15,27)$. Probably, most fragments result from apoptosis, as they range from 180 to 200 base pairs (16). In addition, smaller and larger fragments have also been reported, suggesting that necrosis is also a probable source (28). Macrophages seem to contribute to the releasing process after necrotic tumor cells phagocytosis (29). When in circulation, cfDNA can be linked to proteins or, alternatively, be transported by vesicles, such as exosomes or apoptotic bodies, through a process that, although not completely clarified, seems to contribute to distant spreading and metastasis $(30,31)$. In addition, there is evidence that a fraction of tumor DNA circulates in the blood linked to the blood cells surface (i.e. erythrocytes and leukocytes) $(31,32)$. The genetic alterations of cfDNA reflect the genomic alterations of the original tumors and include point mutations, rearrangements, amplifications and gene copy variations (15).

\section{Circulating Tumor Cells}

CTCs released by the primary tumor can be detected in the bloodstream and represent not only an attractive diagnostic method, as a morphologic analysis can be performed, but also an opportunity for molecular characterization, since DNA, RNA and protein information can be obtained (15). During the metastatic process, the tumor cells separate from the primary tumor, migrate through the surrounding tissue and reach lymphatic or blood circulation (33). Two different ways of tumor cell migration have been proposed (34). First, active migration implies that a single or a cluster of tumor cells has gained the ability to move through the extracellular matrix and basement membranes (35). Second, passive migration refers to the growth of tumor mass that pushes single or clusters of tumor cells into the circulation (36) and, as this process is common in epithelial malignancies, CTC frequently maintains the epithelial phenotype and presents epithelial-specific markers, such as the epithelial cell adhesion molecule (EpCAM) $(33,34)$. Epithelial malignancies may also shift their phenotype from epithelial to mesenchymal. Although the meaning of the transition is still on debate, an association with the ability of becoming invasive has been suggested $(37,38)$. In these cells, EpCAM is downregulated 


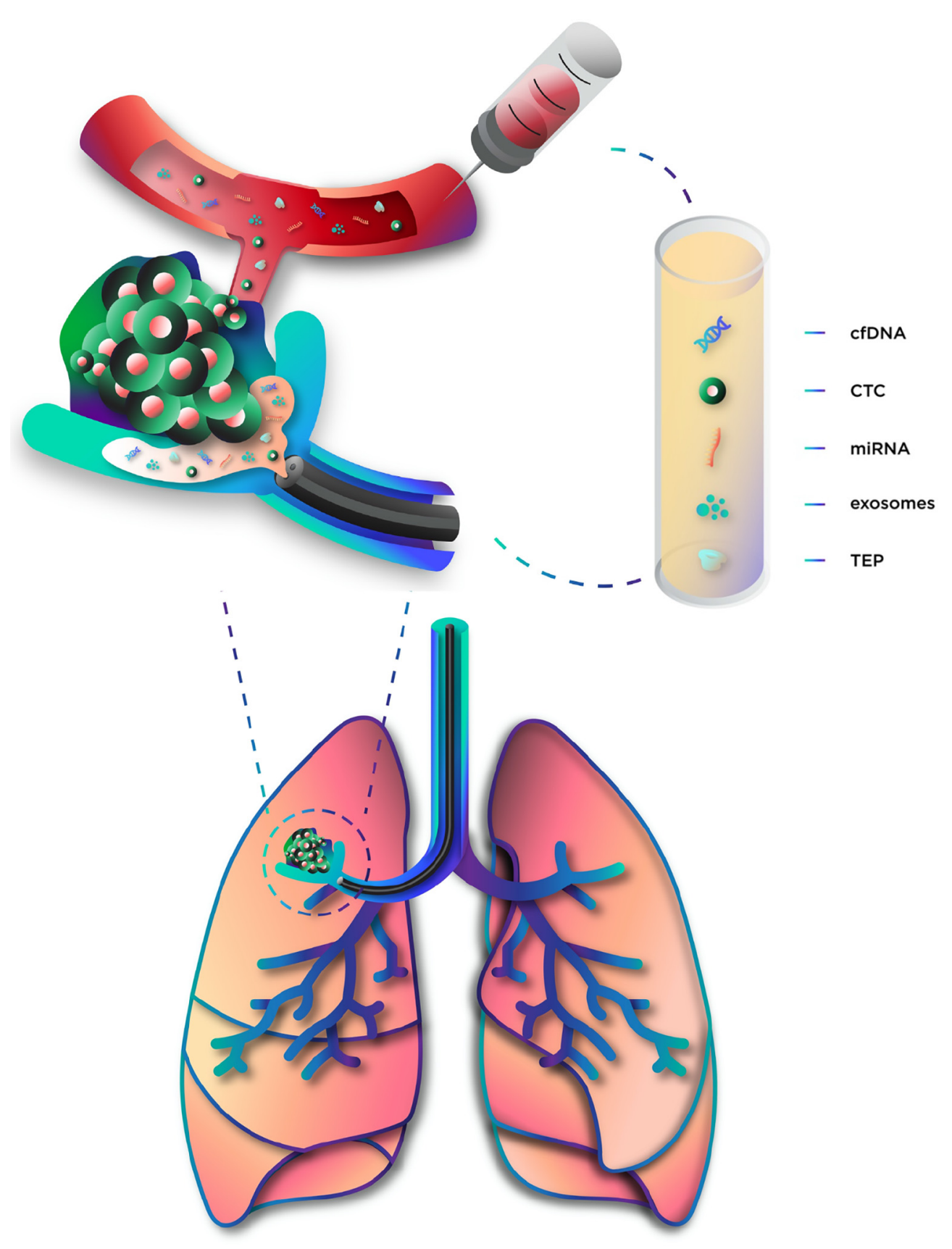

FIGURE 1 | Components of liquid biopsy. cfDNA, circulating cell-free DNA; CTC, circulating tumor cells; miRNA, microRNA; TEP, tumor-educated platelets.

and, thus, cannot be detected by conventional EpCAM-based methods (33). Surviving in the bloodstream is not easy for CTC, since many barriers need to be overcome, namely the forces and stresses created by the blood flow, anoikis and the immune system (33). During this phase, CTCs can be detected in the bloodstream and serve as a biomarker. Tamminga et al. (39) studied the release of CTCs during surgery and identified higher CTCs counts by CellSearch system in the pulmonary vein compared to peripherical circulation, suggesting a clearance mechanism. Since two groups of cells were detected in pulmonary vein samples-the real CTC and benign epithelial cells, the difference between peripherical and central circulation may be explained by the lack of survival ability of benign epithelial cells due to lower tolerance of shearing forces and the mesenchymal environment, leading to their fast clearance or destruction (39). Still, CTCs presence in pulmonary vein at time 
TABLE 1 | Summary of advantages and limitations in LC diagnosis according to liquid biopsy-based biomarker.

\begin{tabular}{|c|c|c|c|}
\hline Biomarkers & Advantages & Limitations & References \\
\hline cfDNA & $\begin{array}{l}\text { - Increased in cancer patients comparing to healthy } \\
\text { individuals; } \\
\text { - Genetic and epigenetic alterations reflect those of } \\
\text { the original tumor; } \\
\text { - } \quad \text { Representation of tumor heterogeneity and } \\
\text { dynamics; } \\
\text { - Highly sensitive assays available (PCR, NGS). }\end{array}$ & $\begin{array}{l}\text { - } \quad \text { Markedly diluted compared to germline circulating DNA; } \\
\text { - } \quad \text { Positively correlates with tumor size and staging; } \\
\text { - } \quad \text { Increased in some benign or premalignant conditions; } \\
\text { - } \quad \text { High costs. }\end{array}$ & $(16,17-18)$ \\
\hline СТC & $\begin{array}{l}\text { - Allows morphologic analysis and tumor molecular } \\
\text { characterization; } \\
\text { - Correlates with prognosis; } \\
\text { - Emerging enrichment and characterization } \\
\text { techniques. }\end{array}$ & $\begin{array}{l}\text { - } \quad \text { No validated assay; } \\
\text { - } \quad \text { Rare in bloodstream and surrounded by blood cells; } \\
\text { - } \quad \text { Role in cancer spreading to mesenchymal transition with loss of epithelial-specific markers; } \\
\text { Rolarified. }\end{array}$ & $(17,19,20)$ \\
\hline miRNA & $\begin{array}{l}\text { Different profiles among early-stage cancer } \\
\text { patients; } \\
\text { Stable in most types of body fluids (e.g. respiratory } \\
\text { samples); } \\
\text { - Released by several structures (e.g. exosome, } \\
\text { TEPs). } \\
\text { Commercial kits available for collection. }\end{array}$ & $\begin{array}{l}\text { - High variability, according to patients and technologies, requiring } \\
\text { normalization methods; } \\
\text { - Quantification and detection methods need to be validated } \\
\text { - Unspecific for a cancer type. }\end{array}$ & $(21-22)$ \\
\hline Exosomes & $\begin{array}{l}\text { - } \quad \text { Contains several types of biomarkers such as } \\
\text { proteins and nucleic acids; } \\
\text { - } \quad \text { Increased in lung cancer patients; } \\
\text { - } \quad \text { Stable and accessible in most types of body fluids; } \\
\text { - } \quad \text { Commercial kits available for isolation. }\end{array}$ & $\begin{array}{l}\text { - The extraction approach, detection and characterization methods are } \\
\text { challenge and require standardization; } \\
\text { - High costs }\end{array}$ & $(23-24)$ \\
\hline TEP & 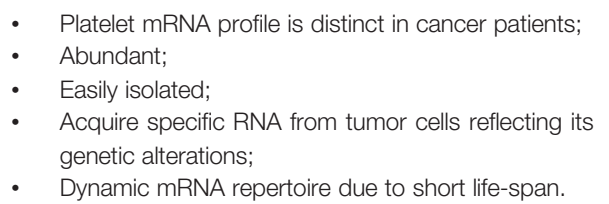 & $\begin{array}{l}\text { - } \quad \text { No validated assay nor standardized approach; } \\
\text { - } \quad \text { Reproducibility; } \\
\text { - } \quad \text { Detection techniques not widely available; } \\
\text { - Time consuming and requires extensive computational resources. }\end{array}$ & $(25-26)$ \\
\hline
\end{tabular}

of surgery was found to be an independent predictor of LCspecific relapse and their genomic features greatly overlap with those of the metastasis detected 10 months later (19). In fact, extravasion from vessels takes place when blood flow slows down, allowing the CTCs to attach the endothelium (40). Once in the metastatic site, tumor cells can initiate a quiescent state, called cancer dormancy (41), until the new surrounding microenvironment allows proliferation (33).

\section{MicroRNA}

In opposition to free RNA molecules that generally do not persist in circulation, cell-free miRNAs can be detected in blood of cancer patients. These fragments of single-stranded non-coding RNA, with a length of 19 to 25 nucleotides, play an important role in gene expression regulation. Mature miRNAs may present in a complex called multiprotein RNA-induced silencing complex (miRISC), which regulates gene expression at a translational level by targeting messenger RNAs (mRNAs) (42). A single miRNA can act on a large number of target mRNAs (43), and a single mRNA target may have multiple miRNA binding sites as well (44), allowing complex combinatorial gene regulation mechanisms. These molecules are involved in several biological processes, such as cell development, differentiation, apoptosis and proliferation (45), and, therefore, changes in the normal cellular miRNA profile can lead to functional abnormalities. In fact, loss or amplification of miRNA genes have been reported in a variety of cancers (46).
Since some of the miRNA targets are oncogenes and tumorsuppressor genes, abnormal miRNA levels may result in oncogene activation and/or loss of tumor suppressing mechanisms, which eventually lead to cancer (42). Briefly, distinct miRNAs profiles on tissue and fluid samples seem to discriminate between healthy and tumor tissues (47). MiRNAs are released into the blood stream and surrounding tissues through exosomes, apoptotic bodies, protein-miRNA complexes, and tumor-educated platelets (TEP) (21), which, in conjunction with their remarkable stability (48) makes miRNA profiling a promising tool for cancer detection.

\section{Exosomes}

Exosomes are extracellular vesicles, with a diameter of 40-100 $\mathrm{nm}$, derived from the progressive accumulation of intraluminal vesicles that are released into the extracellular space by fusion with plasma membrane (49-51). Its content, such as nucleic acids and proteins, and function are intrinsically related to the cells of origin. Tumor cells are known to release greater amounts of exosomes than healthy cells and these structures can be found in almost all body fluids $(23,51,52)$. This vesicles mediate cellto-cell communication and affect many biological processes in LC, contributing to its progression, angiogenesis and metastasis $(53,54)$. Several possible mechanisms through which exosomes communicate with target cells have been described. Exosomal membrane proteins can interact directly with the receptors of a target cell and activate intracellular signaling. Additionally, 
exosomes can merge with the target cell membrane and release its contents into the target cell. This content, that can include proteins, mRNAs, miRNAs and DNA can promote a multiplicity of signaling events in the target cell $(49,54)$. In fact, the exosome and its molecular content represent a source of exclusive information on tumor cell.

\section{Tumor-Educated Platelets}

Platelets are anucleate cells originating from megakaryocytes in bone marrow, known for their role in hemostasis and thrombosis. Despite that, platelets have emerged as having a major impact in both progression and spreading of several solid tumors, including $\operatorname{LC}(55,56)$. Tumor growth, progression and spreading require specific changes in tumor cells and in the surrounding microenvironment, being many of them similar to the physiological role of platelets (55). Although their exact role in cancer is still under investigation, several hypotheses have been proposed. First, TEPs have the ability to create a favorable tumor microenvironment supporting the proliferative signals release, promoting tumor progression, metastasis and angiogenesis in LC (57). Second, TEPs prevent immune destruction by forming a layer that protects the circulating tumor cells from natural killer, other immune cells and from shear forces of circulatory system (58). This coating mechanism may lead to MHC class I transfer to the tumor cells surface, making them unrecognizable by immune cells $(59,60)$ and contributing to distant metastasis formation $(61,62)$. Third, TEPs promote invasion and metastasis through releasing several growth and proangiogenic factors, such as plateletderived growth factor (PDGF) and transforming growth factor $\beta$ (TGF- $\beta$ ) (63). Fourth, TEPs seems to induce angiogenesis by delivering proangiogenic factors to the tumor and stimulating the expression of its own angiogenic factors, such as vascular endothelial growth factor (VEGF), platelet-derived growth factor (PDGF) and basic fibroblast growth factor (bFGF) $(64,65)$. Lastly, TEPs directly interact with tumor cells by acquiring biomolecules, as well as indirectly in response to external signals $(55,66)$.

\section{LIQUID BIOPSY COMPONENTS AS EARLY DETECTION BIOMARKERS: CURRENT EVIDENCE}

\section{Circulating Cell-Free DNA}

CfDNA has been extensively studied in LC and its concentration was found to be increased in LC patients (67). However, some important potential limitations have been discussed concerning its utility as an early detection biomarker. First, cfDNA is markedly diluted compared to circulating germline DNA (68) complicating the detection process. Second, it has been estimated that a minimum $10 \mathrm{~cm}^{3}$ of tumor volume is required to quantify variant allele frequencies of $0.1 \%$, thus hindering early stage tumor detection (69). Definitely cfDNA concentration correlates with tumor size and staging (17), being early-stage LC patients less prone to have representative samples than patients at an advanced stage. Abbosh and colleagues identified several factors related to cfDNA detection, including non-adenocarcinoma histology, high Ki67 expression and lymphovascular invasion. Also, PET FDG avidity was shown to predict cfDNA detection (69). Third, healthy individuals frequently have free DNA in circulation, though in smaller concentrations (70), and benign conditions, such as infections, cardiovascular diseases or other lung diseases are associated to increased cfDNA levels (71-73). However, these limitations may be overcome using highly sensitive genotyping assays, such as digital polymerase chain reaction (PCR) and next-generation sequencing (NGS). Also, a size-based pre-selection of DNA fragments could improve both sensitivity and specificity (74). While PCR methods can only target specific sites in a pre-defined gene and are not able to detect complex genomic alterations, such as gene fusions, NGSbased assays are multiplex methods, also known as massively parallel sequencing assays, allowing a concurrent detection of somatic mutations, including single-nucleotide and copy number variations, gene insertions, deletions or fusions. However, as the portion of sequencing genome increases, a loss of coverage is observed, limiting the ability to call a variant with confidence (75). Thus, the use of panels of primers or probes targeting hotspots or exons of pre-selected genes, such as hybrid capture NGS (76) or amplicon-based NGS $(77,78)$ is a reasonable strategy for cfDNA detection (79). The correct interpretation of cfDNA genotyping can be challenging, with the major limitation being the rate of false negatives that may result from the assay technical limits or, most importantly, from the cfDNA concentration, especially in early stages (18). On the other side, false positives may also occur due to sequencing errors or by the presence of other tumor or premalignant condition (e.g. in clonal hematopoiesis) (79). One must be aware that considering the primary tumor as reference may lead to misclassification as false positives, since a genetic alteration may be present in a tumor site and absent in other due to tumor heterogeneity (79).

Several studies have addressed the potential of cfDNA for early detection, either focusing in its concentration (Table 2) or genetic (Table 3) and epigenetic alterations, more specifically methylation patterns (Table 4).

\section{cfDNA Concentration}

An early study by Sozzi et al. (80) showed that plasma cfDNA concentration was higher among NSCLC patients, mostly with localized disease, than in healthy controls.

Real-time quantitative polymerase chain reaction (RT-PCR) amplification of the human telomerase reverse transcriptase gene (hTERT) was used as an indicator of global amount of plasma cfDNA in several studies $(81,87,88,91)$. The proposed cut-off value to distinguish NSCLC patients from controls ranged from 2 to $25 \mathrm{ng} / \mathrm{ml}$, with sensitivities values varying from 46 to $86 \%$ $(81,88,91)$. Given this results, cfDNA concentration as a noninvasive strategy for early detection of LC was investigated among 1,035 heavy smokers monitored by annual CT for 5 years by Paci et al., but with disappointing results (87).

Human $\beta$-actin gene detected by RT-PCR was another frequent used method for cfDNA detection $(83,85,86,89,90)$. 
TABLE 2 | cfDNA plasma concentration performance as a biomarker for lung cancer diagnosis.

\begin{tabular}{|c|c|c|c|c|c|c|c|}
\hline \multirow[t]{2}{*}{ Study } & \multirow[t]{2}{*}{ Year } & \multirow[t]{2}{*}{ Assay } & \multirow[t]{2}{*}{ Study population } & \multicolumn{4}{|c|}{ Diagnostic performance } \\
\hline & & & & Cut-off & $\mathbf{s}$ & $\mathbf{E}$ & AUC \\
\hline Sozzi (80) & 2001 & $\begin{array}{l}\text { DNA DipStick TM Kit } \\
\text { (Invitrogen, Carlsbad, CA) }\end{array}$ & $\begin{array}{l}43 \text { healthy controls } \\
84 \text { patients with radically resected NSCLC (47 ADCs, } 25 \text { SCC and } 12 \text { others) } \\
\text { Stages: IA: 14; IB: 32; II: 15; III: } 23\end{array}$ & $6-25 \mathrm{ng} / \mathrm{ml}$ & $75 \%$ & $86 \%$ & 0.844 \\
\hline Sozzi (81) & 2003 & RT-PCR using hTERT & $\begin{array}{l}100 \text { controls } \\
100 \text { consecutive patients with NSCLC (58 ADC, } 34 \text { SCC, } 8 \text { others) } \\
\text { Stages: IA: 16; IB: 18; IIB: 25; IIIA: 33; IIIB: 5; IV: } 3\end{array}$ & $25 \mathrm{ng} / \mathrm{ml}$ & $46 \%$ & $99 \%$ & 0.940 \\
\hline Gautschi (82) & 2004 & RT-PCR & $\begin{array}{l}46 \text { healthy controls } \\
185 \text { NSCLC patients (81 ADC, } 49 \text { SCC, } 37 \text { LCC and } 18 \text { undifferentiated) } \\
\text { Stages: I-II: 19; III: 62; IV: } 104\end{array}$ & $10 \mathrm{ng} / \mathrm{ml}$ & - & $98 \%$ & - \\
\hline Herrera (83) & 2005 & $\begin{array}{l}\text { RT-PCR using human } \\
\beta \text {-actin gene }\end{array}$ & $\begin{array}{l}11 \text { healthy volunteers; } 38 \text { esophageal cancer; } 28 \text { GERD } \\
25 \text { NSLC patients undergoing surgery } \\
\text { Stages: I: 10; II: 4; III: 3; IV: 1; Unknown: } 7\end{array}$ & $14.0 \mu \mathrm{g} / \mathrm{L}$ & $48 \%$ & $100 \%$ & 0.630 \\
\hline Ludovini (84) & 2008 & RT-PCR & $\begin{array}{l}66 \text { controls } \\
76 \text { consecutive patients with NSCLC undergoing surgery ( } 37 \text { SCC, } 28 \text { ADC and } \\
11 \text { LCC) } \\
\text { Stages: I: } 20 \text {; II: 40; IIIA: 11; IIIB: } 5\end{array}$ & $3.25 \mathrm{ng} / \mathrm{ml}$ & $80 \%$ & $61 \%$ & 0.820 \\
\hline $\begin{array}{l}\text { Szpechcinski } \\
\text { (85) }\end{array}$ & 2015 & $\begin{array}{l}\text { RT-PCR using human } \\
\beta \text {-actin }\end{array}$ & $\begin{array}{l}40 \text { healthy volunteers } \\
101 \text { patients with chronic respiratory inflammation ( } 34 \text { COPD, } 35 \text { sarcoidosis, } 32 \\
\text { asthma) } \\
50 \text { resectable NSCLC patients ( } 24 \text { ADC, } 22 \text { SCC and } 4 \text { others) } \\
\text { Stages: I: } 22 ; \text { II: } 20 \text {; III: } 8\end{array}$ & $2.80 \mathrm{ng} / \mathrm{ml}$ & $90 \%$ & $81 \%$ & 0.900 \\
\hline $\begin{array}{l}\text { Szpechcinski } \\
\text { (86) }\end{array}$ & 2016 & $\begin{array}{l}\text { RT-PCR using human } \\
\beta \text {-actin }\end{array}$ & $\begin{array}{l}16 \text { healthy controls } \\
28 \text { subjects with benign lung tumors } \\
65 \text { NSCLC patients ( } 28 \text { ADC, } 27 \text { SCC, } 10 \text { others) } \\
\text { Stages: I: } 30 ; \text { II: } 23, \text { III: } 12\end{array}$ & $2.80 \mathrm{ng} / \mathrm{ml}$ & $86 \%$ & $61 \%$ & 0.800 \\
\hline Sozzi (87) & 2009 & RT-PCR using hTERT & $\begin{array}{l}1035 \text { subjects included in a CT screening program (annually CT). During the 5- } \\
\text { year follow-up period, } 956 \text { remained cancer free, } 38 \text { developed LC, and } 41 \\
\text { developed other tumors }\end{array}$ & - & - & - & 0.496 \\
\hline Paci (88) & 2009 & RT-PCR using hTERT & $\begin{array}{l}79 \text { healthy controls. } \\
151 \text { NSCLC patients (65 SCCI, } 61 \text { ADC, } 12 \text { bronchioloalveolar, } 3 \text { LCC, } 2 \text { typical } \\
\text { carcinoid, } 8 \text { others) } \\
\text { Stages: IS: 1; IA: 33; IB: 44; IIA: 5; IIB: 12; IIIA: 24; IIIB: 18; IV: } 4\end{array}$ & $2 \mathrm{ng} / \mathrm{ml}$ & $86 \%$ & $47 \%$ & 0.790 \\
\hline Yoon (89) & 2009 & $\begin{array}{l}\text { RT-PCR using human } \\
\beta \text {-actin gene }\end{array}$ & $\begin{array}{l}105 \text { healthy controls } \\
102 \text { LC patients (67 ADC, } 16 \text { SCC, } 10 \text { SCLC and } 9 \text { others) } \\
\text { Stages in SCLC: localized: 5; extensive: } 4 \\
\text { Stages in NSCLC: I: 8; II: 2; III: 19; IV: } 64\end{array}$ & - & - & - & 0.860 \\
\hline $\begin{array}{l}\text { Van der Drift } \\
\text { (90) }\end{array}$ & 2010 & $\begin{array}{l}\text { RT-PCR using human } \\
\beta \text {-actin gene }\end{array}$ & $\begin{array}{l}21 \text { controls } \\
46 \text { untreated NSCLC patients (21 SCC, } 20 \text { ADC, } 5 \text { LCC) } \\
\text { Stages: I: 11; II: 6; III: 12; IV: 15; Unknown: } 2\end{array}$ & $>32 \mathrm{ng} / \mathrm{ml}$ & $52 \%$ & $67 \%$ & 0.660 \\
\hline Catarino (91) & 2012 & RT-PCR using hTERT & $\begin{array}{l}205 \text { controls } \\
104 \text { NSCLC patients (38 SCC, } 54 \text { ADC and } 12 \text { others) } \\
\text { Stages: I/II: 4; III/IV: } 100\end{array}$ & $20 \mathrm{ng} / \mathrm{ml}$ & $79 \%$ & $83 \%$ & 0.880 \\
\hline
\end{tabular}

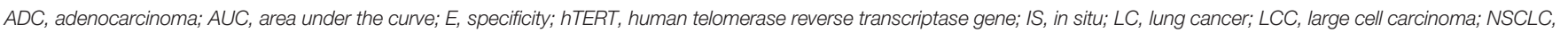
non-small cell lung cancer; $S$, sensitivity; SCC, squamous cell carcinoma; RT-PCR, real time polymerase chain reaction.

While some studies failed in demonstrate the utility of cfDNA $(83,90)$, others have shown favorable results $(85,86,89)$. Szpechcinski and colleagues studied not only LC patients and healthy controls, but also patients with benign lung diseases, found significantly higher plasma cfDNA levels among NSCLC patients than in those with chronic respiratory inflammation and healthy individuals $(85,86)$. A cut-off value of $2.8 \mathrm{ng} / \mathrm{ml}$ was proposed to discriminate NSCLC patients from healthy individuals, with sensitivity and specificity values ranging from 86 to $90 \%$ and 61 to $81 \%$, respectively $(85,86)$.

The relationship between cfDNA levels and tumor histological type or staging is controversial, with several studies reporting no association $(84,86,88,90,91)$, and others highlighting a difference related to disease staging $(82,83,87)$.

\section{cfDNA Genetic Alterations}

\section{Single Biomarker}

Epidermal growth factor receptor (EGFR) is one of the most studied genes in LC, as the presence of certain mutations in this gene are considered markers of efficacy of target therapies. EGFR mutations detection in cfDNA has been also exploited in diagnostic setting $(92-94,96,97)$, and two recent works focused on early stage LC patients. The first one, aimed to determine whether the electric field-induced release and measurement-EFIRM technology was able to detect exon 19 deletions and L858R EGFR mutations in patients with early stage NSCLC (97). The authors obtained a concordance rate between plasma and nodule biopsy of $100 \%$ and a global specificity of 95\% (97). A second study, by Wan et al. (96) compared EGFR 


\begin{tabular}{|c|c|c|c|c|c|c|c|}
\hline \multirow[t]{2}{*}{ Study } & \multirow[t]{2}{*}{ Year } & \multirow[t]{2}{*}{ Assay } & \multirow{2}{*}{$\begin{array}{l}\text { Genetic } \\
\text { alteration }\end{array}$} & \multirow[t]{2}{*}{ Study population } & \multicolumn{3}{|c|}{ Diagnostic performance } \\
\hline & & & & & s & E & AUC \\
\hline \multicolumn{8}{|l|}{ Single biomarker } \\
\hline Zhao (92) & 2013 & $\begin{array}{l}\text { Mutant-enriched PCR and } \\
\text { sequencing }\end{array}$ & $\begin{array}{l}\text { EGFR mutations (exon } 19 \text { and } \\
\text { 20) and EGFR exon } 19 \\
\text { deletions }\end{array}$ & $\begin{array}{l}111 \text { NSCLC patients including } 35 \text { SCC, } 73 \text { ADC and } 3 \\
\text { others. }\end{array}$ & $36 \%$ & $96 \%$ & - \\
\hline Jing (93) & 2014 & HRM analysis & $\begin{array}{l}\text { EGFR mutations (exons 18, } \\
19,20 \text { and } 21 \text { ) }\end{array}$ & $\begin{array}{l}\text { Stages: I: 22; II: 10; IIIA: 19; IIIB: 14; IV: } 46 \\
120 \text { NSCLC patients including } 70 \text { ADC and } 50 \text { non-ADC. } \\
\text { Stages: I/II: 38; III/IV: } 82\end{array}$ & $78 \%$ & $97 \%$ & - \\
\hline Uchida (94) & 2015 & NGS & $\begin{array}{l}\text { EGFR mutations (exon } 19 \text {, } \\
20,21 \text { ) }\end{array}$ & $\begin{array}{l}288 \text { NSCLC patients including } 274 \text { ADC, } 7 \text { SCC, and } 7 \\
\text { others } \\
\text { Stages: I: 64; II: 19; III: 53; IV: } 146\end{array}$ & $\begin{array}{l}\text { Exon } 19 \text { deletions: } \\
51 \% \\
\text { L858R mutation: } \\
52 \%\end{array}$ & $\begin{array}{l}\text { Exon } 19 \text { deletions: } \\
\text { 98\% } \\
\text { L858R mutation: } \\
\quad 94 \%\end{array}$ & - \\
\hline $\begin{array}{l}\text { Fernandez-Cuesta } \\
\text { (95) }\end{array}$ & 2016 & NGS & TP53 (exons 2 to 10) & $\begin{array}{l}123 \text { non-cancer controls; } 51 \text { SCLC patients } \\
\text { Stages: I: 7; II: 7; III: 28; IV: } 9\end{array}$ & $49 \%$ & $89 \%$ & - \\
\hline Wan (96) & 2018 & ARMS-PCR & $\begin{array}{l}\text { EGFR mutations (exon } 19 \\
\text { deletion, T790M, L858R) }\end{array}$ & $\begin{array}{l}69 \text { controls; } 284 \text { early-stage NSCLC patients ( } 35 \text { ADC, } \\
231 \text { SCC and } 18 \text { others) } \\
\text { Stages: I: } 107 ; \text { II: } 177\end{array}$ & $14 \%$ & $92 \%$ & - \\
\hline Wei (97) & 2018 & EFIRM & $\begin{array}{l}\text { EGFR mutations (exon } 19 \\
\text { deletion and L858R) }\end{array}$ & $\begin{array}{l}23 \text { patients with benign pulmonary nodules } 21 \text { early-stage } \\
\text { ADC patients ( } 12 \text { L858R and } 9 \text { exon } 19 \text { deletion EGFR } \\
\text { variants) } \\
\text { Stages: I: } 18 ; \text { II: } 3\end{array}$ & $\begin{array}{l}\text { Exon } 19 \text { deletions: } \\
77 \% \\
\text { L858R mutation: } \\
\quad 92 \%\end{array}$ & $95 \%$ & $\begin{array}{l}\text { Exon } 19 \text { deletions: } \\
0.978 \\
\text { L858R mutation: } \\
0.973\end{array}$ \\
\hline \multicolumn{8}{|c|}{ Combination biomarker } \\
\hline Newman (98) & 2014 & CAPP-Seq & 139 cancer-related genes & $\begin{array}{l}5 \text { healthy controls } 17 \text { NSCLC patients (14 ADC, } 2 \text { SCC and } \\
1 \text { LCC) } \\
\text { Stages: I: 4; II: 1; III: 6; IV: } 6\end{array}$ & $85 \%$ & $96 \%$ & 0.950 \\
\hline Guo (99) & 2016 & NGS & 50 cancer-related genes & $\begin{array}{l}41 \text { NSCLC patients (33 ADC, } 6 \text { SCC, } 2 \text { others) } \\
\text { Stages: I: 23; II: 7; III: 10; IV: } 1\end{array}$ & $69 \%$ & $93 \%$ & - \\
\hline Chen (100) & 2016 & NGS & 50 cancer-related genes & $\begin{array}{l}58 \text { NSCLC patients (51 ADC and seven SCC) } \\
\text { Stages: I: 46; II: } 12\end{array}$ & $54 \%$ & $47 \%$ & - \\
\hline Cohen (101) & 2018 & $\begin{array}{l}\text { CancerSEEK (NGS and } \\
\text { protein immunoassay) }\end{array}$ & $\begin{array}{l}8 \text { proteins and } 16 \text { cancer- } \\
\text { related genes }\end{array}$ & $\begin{array}{l}812 \text { healthy controls } 1005 \text { patients with stage I to III } \\
\text { cancers including } 103 \text { NSCLC and } 1 \text { SCLC } \\
\text { Stages: I: } 46 \text {; II: } 21 ; \text { III: } 31\end{array}$ & $70 \%$ & $99 \%$ & 0.910 \\
\hline Ye (102) & 2018 & NGS & 140 cancer-related genes & $\begin{array}{l}35 \text { lung surgery candidate nodule patients (four benign } \\
\text { nodule patients, } 31 \text { LC patients: } 2 \text { ADC IS, } 25 \text { ADC, } 1 \\
\text { SCC, } 3 \text { other) } \\
\text { Stages: I: } 21 \text {; II: 5; III: 4; not defined: } 1\end{array}$ & $33 \%$ & $100 \%$ & - \\
\hline Peng (103) & 2019 & NGS & 65 cancer-related genes & $\begin{array}{l}56 \text { benign lung lesions patients136 LC patients (100 ADC, } \\
28 \text { SCC, } 1 \text { SCLC, } 7 \text { others) } \\
\text { Stages: I: 87; II: 29; III: 17; IV: } 3\end{array}$ & $69 \%$ & $96 \%$ & - \\
\hline Tailor (104) & 2019 & NGS & & $\begin{array}{l}16 \text { benign lung lesion patients } 17 \text { LC patients (10 ADC, } 6 \\
\text { SCC, } 1 \text { LCC) } \\
\text { Stages: I: 8; II: 2; III: 5; IV: } 2\end{array}$ & $82 \%$ & - & - \\
\hline Leung (105) & 2020 & $\begin{array}{l}\text { COLD-PCR assay coupled } \\
\text { with high-resolution melt } \\
\text { analysis }\end{array}$ & KRAS, EGFR, and TP53 & $\begin{array}{l}26 \text { controls } 192 \text { patients referred to surgery (106 primary } \\
\text { LC, } 54 \text { secondary cancer, } 6 \text { another primary thoracic } \\
\text { malignancy) } \\
\text { Stages: I: } 52 \text {; II: 33; III: 16; IV: 1; Missing: } 4\end{array}$ & $75 \%$ & $89 \%$ & - \\
\hline
\end{tabular}

ADC, adenocarcinoma; ARMS-PCR, Amplification-refractory-mutation system-based PCR assays; AUC, area under the curve; CAPP-Seq, CAncer Personalized Profiling by deep Sequencing; COLD, Lower denaturation temperature; E, specificity; EFIRM, Electric field-induced release and measurement; HRM, High resolution melting; IS, in situ; LC, lung cancer; LCC, large cell carcinoma; NSCLC, non-Small cell lung cancer; S, sensitivity; SCC, squamous cell carcinoma. SCLC, small cell lung cancer. 


\begin{tabular}{|c|c|c|c|c|c|c|c|c|}
\hline \multirow[t]{2}{*}{ Study } & \multirow[t]{2}{*}{ Year } & \multirow[t]{2}{*}{ Assay } & \multirow[t]{2}{*}{ Methylated genes } & \multirow[t]{2}{*}{ Study population } & \multirow[t]{2}{*}{ Sample } & \multicolumn{3}{|c|}{ Diagnostic performance } \\
\hline & & & & & & $\mathbf{s}$ & $\mathbf{E}$ & AUC \\
\hline \multicolumn{9}{|c|}{ Single-Dual biomarker } \\
\hline Wang (106) & 2007 & $\begin{array}{l}\text { Methylation-Specific } \\
\text { RT-PCR }\end{array}$ & RASSF1A & $\begin{array}{l}15 \text { healthy controls } \\
35 \text { benign pulmonary diseases patients } \\
80 \text { LC patients ( } 40 \text { ADC, } 26 \text { SCC, nine } \\
\text { adenosquamous carcinoma, five SCLC) } \\
\text { Stages: I: 9; II: 18; III: 29; IV: } 24\end{array}$ & Serum & $34 \%$ & $100 \%$ & - \\
\hline Schmidt (107) & 2010 & $\begin{array}{l}\text { Methylation-Specific } \\
\text { RT-PCR }\end{array}$ & SHOX2 & $\begin{array}{l}242 \text { controls } \\
281 \text { LC patients (109 ADC, } 103 \text { SCC, } 37 \\
\text { NOS NSCLC, } 29 \text { SCLC, three others) } \\
\text { Stages: I: 59; II: 43; III: 108; IV: 62; } \\
\text { unknown: } 9\end{array}$ & $\begin{array}{l}\text { Bronchial } \\
\text { aspirates }\end{array}$ & $68 \%$ & $95 \%$ & 0.860 \\
\hline Kneip (108) & 2011 & $\begin{array}{l}\text { Methylation-Specific } \\
\text { RT-PCR }\end{array}$ & SHOX2 & $\begin{array}{l}155 \text { controls } \\
188 \text { LC patients ( } 38 \text { SCC, } 31 \text { SCC, } 15 \\
\text { SCLC, } 104 \text { other) } \\
\text { Stages: I:37; II:29; III:53; IV:42; } \\
\text { unknown:27 }\end{array}$ & Plasma & $60 \%$ & $90 \%$ & 0.780 \\
\hline Hwang (109) & 2011 & Pyrosequencing & HOXA9 & $\begin{array}{l}51 \text { healthy controls } \\
58 \text { benign lung diseases patients } \\
76 \text { LC patients (42 ADC and } 34 \text { SCC). } \\
\text { Stages: I: 14; II: 5; III: } 28 \text {; IV: } 29\end{array}$ & Induced sputum & $71 \%$ & $55 \%$ & 0.969 \\
\hline Dietrich (110) & 2012 & Epi proLung BL & SHOX2 and PTGER4 & $\begin{array}{l}125 \text { controls } \\
125 \text { LC patients ( } 26 \text { ADC, } 28 \text { SCC, } 40 \\
\text { SCLC, } 9 \text { NSCLC NOS, } 32 \text { others) }\end{array}$ & $\begin{array}{l}\text { Bronchial } \\
\text { aspirates }\end{array}$ & $78 \%$ & $96 \%$ & 0.940 \\
\hline $\begin{array}{l}\text { Ponomaryova } \\
\text { (111) }\end{array}$ & 2013 & $\begin{array}{l}\text { Methylation-Specific } \\
\text { RT-PCR }\end{array}$ & RARB2and RASSF1A & $\begin{array}{l}32 \text { healthy donors } \\
60 \text { NSCLC patients ( } 40 \text { SCC and } 20 \text { ADC) } \\
\text { Stages: I/II: 20; III: } 40\end{array}$ & $\begin{array}{l}\text { Plasma and cell- } \\
\text { surface-bound } \\
\text { circulating DNA }\end{array}$ & $85 \%$ & $75 \%$ & - \\
\hline $\begin{array}{l}\text { Powrózek } \\
2014 \text { (112) }\end{array}$ & 2014 & $\begin{array}{l}\text { Methylation-specific } \\
\text { RT-PCR }\end{array}$ & Septin 9 & $\begin{array}{l}100 \text { healthy controls } \\
70 \text { LC patients ( } 20 \mathrm{ADC}, 20 \mathrm{SCC}, 23 \\
\text { SCLC, seven others) } \\
\text { Stages: IIA-IIIA: 23; IIIB-IV: } 47\end{array}$ & Plasma & $44 \%$ & $92 \%$ & \\
\hline Konecny (113) & 2016 & Epi proLung BL & SHOX2 & $\begin{array}{l}69 \text { suspected LC patients; } 31 \text { excluded } \\
\text { LC (controls) and } 38 \text { LC confirmed } \\
\text { including } 28 \text { NSCLC and one SCLC. } \\
\text { Stages: I-II: 5; III-IV: } 30 \text {; unknown: } 3\end{array}$ & $\begin{array}{l}\text { Bronchial lavage } \\
\text { Plasma }\end{array}$ & $\begin{array}{l}89 \% \\
81 \%\end{array}$ & $\begin{array}{l}85 \% \\
79 \%\end{array}$ & $\begin{array}{l}0.890 \\
0.870\end{array}$ \\
\hline $\begin{array}{l}\text { Powrózek } \\
\text { (114) }\end{array}$ & 2016 & $\begin{array}{l}\text { Methylation-specific } \\
\text { RT-PCR }\end{array}$ & DCLK1 & $\begin{array}{l}95 \text { healthy controls } \\
65 \text { LC patients (22 ADC, } 20 \text { SCC, } 19 \\
\text { SCLC, four others) } \\
\text { Stages: IIA-IIB: 7; IIIA: 21; IIIB-IV: } 37\end{array}$ & Plasma & $49 \%$ & $92 \%$ & - \\
\hline Ren (115) & 2017 & $\begin{array}{l}\text { Methylation-specific } \\
\text { RT-PCR }\end{array}$ & SHOX2 and RASSF1A & $\begin{array}{l}130 \text { controls ( } 112 \text { benign lung disease } \\
\text { patients and } 18 \text { patients with other } \\
\text { malignancies) } \\
52 \text { patients with no exact diagnosis } \\
123 \text { LC patients including } 82 \text { ADC, } 17 \\
\text { SCC, eight SCLC, } 16 \text { others } \\
\text { Stages: 0: 4; I: } 47 \text {; II: } 13 \text {; III: } 19 \text {; IV: } 25 \text {; } \\
\text { unknown: } 15\end{array}$ & $\begin{array}{l}\text { Bronchoalveolar } \\
\text { lavage }\end{array}$ & $72 \%$ & $90 \%$ & - \\
\hline
\end{tabular}




\begin{tabular}{|c|c|c|c|c|c|c|c|c|}
\hline \multirow[t]{2}{*}{ Study } & \multirow[t]{2}{*}{ Year } & \multirow[t]{2}{*}{ Assay } & \multirow[t]{2}{*}{ Methylated genes } & \multirow[t]{2}{*}{ Study population } & \multirow[t]{2}{*}{ Sample } & \multicolumn{3}{|c|}{ Diagnostic performance } \\
\hline & & & & & & s & E & AUC \\
\hline Nunes (116) & 2019 & $\begin{array}{l}\text { Methylation-specific } \\
\text { RT-PCR }\end{array}$ & $\begin{array}{l}4 \text { genes: APC, HOXA9, RARß2, } \\
\text { and RASSF1A }\end{array}$ & $\begin{array}{l}28 \text { benign lung diseases patients } \\
129 \text { LC cancer patients (65 ADC, } 42 \text { SCC, } \\
19 \text { SCLC) } \\
\text { Stages: I: 15; II: 11; III: } 27 \text {; IV: } 76\end{array}$ & Plasma & $\begin{array}{c}\text { APC: } 25 \% \\
\text { RASSF1A: } 24 \% \\
\text { APC and RASSF1A: } 38 \%\end{array}$ & $\begin{array}{l}\text { APC: } 96 \% \\
\text { RASSF1A: 95\% } \\
\text { APC and } \\
\text { RASSF1A: 93\% }\end{array}$ & $\begin{array}{c}\text { APC: } 0.622 \\
\text { RASSF1A: } 0.591\end{array}$ \\
\hline \multicolumn{9}{|c|}{ Combination biomarker } \\
\hline Fujiwara (117) & 2005 & $\begin{array}{l}\text { Methylation-Specific } \\
\text { RT-PCR }\end{array}$ & $\begin{array}{l}\text { RAR } \beta, \text { p16 }{ }^{\text {INK4a }} \text {, DAPK, } \\
\text { RASSF1A, and MGMT }\end{array}$ & $\begin{array}{l}100 \text { non-malignant diseases patients } \\
\text { nine other malignancies } \\
91 \text { LC patients ( } 64 \text { ADC, } 21 \text { SCC, four } \\
\text { SCLC, two carcinoid). } \\
\text { Stages: I: 53; II: } 7 \text {; III: 22; IV: } 9\end{array}$ & Serum & $50 \%$ & $85 \%$ & - \\
\hline Hsu (118) & 2007 & $\begin{array}{l}\text { Methylation-Specific } \\
\text { RT-PCR }\end{array}$ & $\begin{array}{l}\text { BLU, CDH13,FHIT, p16, RARB, } \\
\text { and RASSF1A }\end{array}$ & $\begin{array}{l}36 \text { cancer-free controls } \\
63 \text { NSCLC patients ( } 41 \text { ADCs, } 13 \text { SCC) } \\
\text { Stages: I-II: } 41 \text {; III-IV: } 21 \text {; Not staged: } 1\end{array}$ & Plasma & $73 \%$ & $82 \%$ & \\
\hline Zhang (119) & 2011 & $\begin{array}{l}\text { Methylation-Specific } \\
\text { RT-PCR }\end{array}$ & $\begin{array}{l}9 \text { genes: APC, CDH13, DLEC1, } \\
\text { EFEMP1, KLK10, p16 }{ }^{\text {INK4A }} \\
\text { RAR } \beta, \text { RASSF1A, SFRP1 }\end{array}$ & $\begin{array}{l}50 \text { cancer-free controls } \\
110 \text { NSCLC patients (Stage I/II) }\end{array}$ & Plasma & $\begin{array}{l}90 \% \\
\text { APC, RASSF1A, CDH13, } \\
\text { KLK10 and DLEC1: } 84 \%\end{array}$ & $\begin{array}{c}58 \% \\
\text { APC, RASSF1A, } \\
\text { CDH13, KLK10 } \\
\text { and DLEC1: } 74 \%\end{array}$ & - \\
\hline Begum (120) & 2011 & $\begin{array}{l}\text { Methylation specific } \\
\text { RT-PCR }\end{array}$ & $\begin{array}{l}6 \text { genes: APC, AIM1, CDH1, } \\
\text { DCC, MGMT and RASSF1A }\end{array}$ & $\begin{array}{l}30 \text { controls } \\
76 \text { LC patients (36 ADC, } 26 \text { SCC, } 14 \\
\text { others) } \\
\text { Stages: I: } 41 \text {; II: 17; III: 11; IV: 5; } \\
\text { unknown: } 2\end{array}$ & Serum & $84 \%$ & $57 \%$ & - \\
\hline $\begin{array}{l}\text { Nikolaidis } \\
\text { (121) }\end{array}$ & 2012 & $\begin{array}{l}\text { Methylation specific } \\
\text { RT-PCR }\end{array}$ & $\begin{array}{l}4 \text { genes: TERT, WT1, p16 and } \\
\text { RASSF1 }\end{array}$ & $\begin{array}{l}109 \text { controls; } \\
139 \text { LC cases (22 ADC, } 31 \text { SCC, } 39 \\
\text { SCLC, } 16 \text { LCC, } 31 \text { others) } \\
\text { Stages: T1: 46; T2: 91; T3: 20; T4: 53; } \\
\text { NO: 94; N1: 35; N2: 63; N3: } 13\end{array}$ & Bronchial lavage & $82 \%$ & $91 \%$ & - \\
\hline \multirow[t]{2}{*}{$\begin{array}{l}\text { Diaz-Lagares } \\
(122)\end{array}$} & 2016 & Pyrosequencing & $\begin{array}{l}4 \text { genes: BCAT1, CDO1, TRIM58, } \\
\text { and ZNF177 }\end{array}$ & $\begin{array}{l}\text { Bronchial aspirates cohort: } \\
-29 \text { cancer-free controls } \\
-51 \text { LC patients (17 ADC, } 19 \text { SCC, } 11 \\
\text { NSCLC NOS, } 4 \text { other) }\end{array}$ & $\begin{array}{l}\text { Bronchial } \\
\text { aspirates } \\
\text { Bronchioalveolar } \\
\text { lavages }\end{array}$ & $\begin{array}{l}84 \% \\
\sim 80 \%\end{array}$ & $\begin{array}{l}81 \% \\
\sim 80 \%\end{array}$ & $\begin{array}{l}0.910 \\
0.850\end{array}$ \\
\hline & & & & $\begin{array}{l}\text { Stages: I: 5; II: 6; III: 21; IV: 18; unknown: } \\
1 \\
\text { BAL cohort: } \\
\text {-29 cancer-free controls } \\
\text {-82 LC patients (25 ADC, } 40 \text { SCC, } 12 \\
\text { SCLC, } 5 \text { others) } \\
\text { Stages: I: 17; II: 8; III: 20; IV: 18; } \\
\text { unknown: 19 } \\
\text { Sputum cohort: } \\
\text {-26 cancer-free controls } \\
\text {-72 LC patients (38 ADC, } 24 \text { SCC, } 5 \\
\text { SCLC, } 4 \text { other) } \\
\text { Stages: I: 12; II: 13; III: 23; IV: 19; } \\
\text { unknown: } 5\end{array}$ & Sputum & $\sim 65 \%$ & $\sim 65 \%$ & 0.930 \\
\hline
\end{tabular}




\begin{tabular}{|c|c|c|c|c|c|c|c|c|}
\hline \multirow[t]{2}{*}{ Study } & \multirow[t]{2}{*}{ Year } & \multirow[t]{2}{*}{ Assay } & \multirow[t]{2}{*}{ Methylated genes } & \multirow[t]{2}{*}{ Study population } & \multirow[t]{2}{*}{ Sample } & \multicolumn{3}{|c|}{ Diagnostic performance } \\
\hline & & & & & & s & E & AUC \\
\hline Ma (123) & 2016 & $\begin{array}{l}\text { Quantum dots } \\
\text { combined with } \\
\text { FRET }\end{array}$ & $\begin{array}{l}\text { PCDHGB6, HOXA9 and } \\
\text { RASSF1A }\end{array}$ & $\begin{array}{l}50 \text { controls } \\
50 \text { NSCLC patients (24 ADC and } 16 \text { SCC) } \\
\text { Stages: I: } 23 \text {; II: } 17\end{array}$ & Bronchial brushing & $80 \%$ & $100 \%$ & 0.907 \\
\hline Hulbert (124) & 2017 & $\begin{array}{l}\text { Methylation-specific } \\
\text { RT-PCR }\end{array}$ & $\begin{array}{l}6 \text { genes: SOX17, TAC1, HOXA7, } \\
\text { CDO1, HOXA9, ZFP42 }\end{array}$ & $\begin{array}{l}60 \text { cancer-free controls } \\
150 \text { LC cases (121 ADC, } 26 \text { SCC, } 3 \\
\text { others) } \\
\text { Stages: IA-IB: 136; IIA: } 14\end{array}$ & Plasma & $\begin{array}{c}\text { TAC1, HOXA17 and } \\
\text { SOX17: } 93 \% \\
6 \text { genes, age, PY, COPD } \\
\text { and FVC: } 91 \% \\
\text { CDO1, TAC1 and } \\
\text { SOX17: } 86 \% \\
6 \text { genes, age, PY, COPD } \\
\text { and FVC: } 85 \%\end{array}$ & $\begin{array}{l}\text { CDO1, TAC1 and } \\
\text { SOX17:78\% }\end{array}$ & $\begin{array}{c}\text { TAC1, HOXA17 } \\
\text { and SOX17: } 0.890 \\
6 \text { genes, age, PY, } \\
\text { COPD and FVC: } \\
0.850 \\
\text { CDO1, TAC1 and } \\
\text { SOX17: } 0.770 \\
6 \text { genes, age, PY, } \\
\text { COPD and FVC: } \\
0.890\end{array}$ \\
\hline Ooki (125) & 2017 & $\begin{array}{l}\text { Methylation-specific } \\
\text { RT-PCR }\end{array}$ & $\begin{array}{l}6 \text { genes: CDO1, HOXA9,AJAP1, } \\
\text { PTGDR, UNCX, and MARCH11 }\end{array}$ & $\begin{array}{l}42 \text { controls } \\
43 \text { primary NSCLC with matched serum } \\
\text { samples from stage IA ADC } \\
40 \text { serum samples from stage IA SCC } \\
70 \text { pleural effusions samples } \\
49 \text { ascites samples }\end{array}$ & $\begin{array}{l}\text { Serum } \\
\text { Pleural effusions }\end{array}$ & $\begin{array}{l}\text { ADC: } 72 \% S C C: \text { 60\% } \\
\text { 4-gene panel (CDO1, } \\
\text { PTGDR, UNCX, and } \\
\text { MARCH11): 70\% } \\
\text { 5-gene panel (CDO1, } \\
\text { AJAP1, PTGDR, UNCX, } \\
\text { and MARCH11): } 76 \%\end{array}$ & $\begin{array}{c}\text { 71\% } \\
\text { 4-gene panel } \\
\text { (CDO1, PTGDR, } \\
\text { UNCX, MARCH11): } \\
\text { 85\% } \\
\text { 5-gene panel } \\
\text { (CDO1, AJAP1, } \\
\text { PTGDR, UNCX, } \\
\text { MARCH11): 76\% }\end{array}$ & $\begin{array}{l}- \\
-\end{array}$ \\
\hline Hubers (126) & 2017 & $\begin{array}{l}\text { Methylation-specific } \\
\text { RT-PCR }\end{array}$ & $\begin{array}{l}7 \text { genes: RASSF1A, APC, } \\
\text { cytoglobin,3OST2, PRDM14, } \\
\text { FAM19A4 and PHACTR3 }\end{array}$ & $\begin{array}{l}219 \text { controls } \\
56 \text { LC patients ( } 34 \text { ADC, } 7 \text { SCC, } 2 \text { SCLC, } \\
13 \text { others } \\
\text { Stages: I:36, II:4, III:6, IV:10 }\end{array}$ & Sputum & $17 \%$ & $93 \%$ & - \\
\hline Liang (127) & 2019 & Methyl-seq & 9 genes & $\begin{array}{l}27 \text { controls } \\
39 \text { LC patients (32 ADC, } 6 \text { SCC and } 1 \\
\text { other) } \\
\text { Stages: IA: 20; IB: 7; IIA: 1; Later stages: } \\
\text { 10; unknown: } 1\end{array}$ & Plasma & $80 \%$ & $85 \%$ & 0.820 \\
\hline
\end{tabular}

ADC, adenocarcinoma; AUC, area under the curve; COPD, chronic obstructive pulmonary disease; E, specificity; FRET, fluorescence resonance energy transfer; FVC, forced vital capacity; IS, in situ; LC, lung cancer; LCC, large cell carcinoma; NSCLC, non-small cell lung cancer; NOS-NSCLC, not otherwise specified non-small cell lung cancer; PY, pack-years; S, sensitivity; SCC, squamous cell carcinoma; SCLC, small cell lung cancer. 
exon 19 deletions, T790M and L858R, using amplificationrefractory-mutation system-based PCR assays (ARMS-PCR) in DNA isolated from nanoscale extracellular vesicles and cfDNA in NSCLC patients and controls. Although none of them were correlated with tumor volume, DNA isolated from extracellular vesicles was better than cfDNA for mutation detection among early stage NSCLC patients (96).

As TP53 is inactivated in most SCLC, Fernandez-Cuesta and colleagues (95) assessed the presence of exon 2 to 10 mutations in plasma cfDNA from 51 SCLC patients and 123 controls and showed that, despite their occurrence in control samples due to interference of somatic mutations, they were significantly more frequent in SCLC cases, even when stratified by stage (95).

\section{Combination Biomarker}

Despite recurrent point mutations in cancer-related genes, such as EGFR, have been frequently used, a non-negligible proportion of patients have no mutations in these selected genes. Instead of using only a single gene, several studies used multigene panels towards to improve the test performance. An early example is the CAncer Personalized Profiling by deep Sequencing (CAPP-Seq) developed by Newman and collaborators (98). This low-cost method covered multiple classes of somatic alterations and identified mutations in more than $95 \%$ of tumors, however showing low sensitivity for stage I patients (98). Nonetheless, in a final analysis, CAPP-Seq showed to potentially improve the low positive predictive value of LDCT screening (98). Cohen et al. (101) described the CancerSEEK, a blood test composed by levels of eight proteins and cfDNA mutations in 16 cancerrelated genes that can detect eight frequent types of cancer, including LC. Globally, the results showed a sensitivity of $70 \%$ and a specificity of $99 \%$. But a reduced sensitivity among stage I patients and a disappointing sensitivity for LC were noticed (101).

A malignancy prediction model for lung nodules was proposed by Ye et al. (102) in order to complement LDCT screening. Fixing the cut-off values in 4 for mutation score and in 0.3 for tumor mutation burden of cfDNA, the model predicted $33 \%$ of malignant adenocarcinoma samples with $100 \%$ specificity (102). In the same study, the concordance rate of driver mutations between cfDNA and tumor was low, suggesting that improving sensitivity of early stage LC detection by increasing sequencing depth or coverage may be inappropriate (102). More recently, a pilot investigation by Tailor et al. (104) using whole-exome sequencing (WES) in plasma cfDNA and matched peripheral blood mononuclear cell germline DNA from patients with a CT-detected pulmonary nodules, showed that the number of variants was significantly higher in the LC group than in controls and, when selecting 10 variants, $82 \%$ of LC patients were detected, showing the potential role for early LC detection in patients with CT-detected lung lesions (104).

\section{cfDNA Epigenetic Alterations Single-Dual Biomarker}

One of the most studied epigenetic mechanisms is DNA methylation, which consists in the addition of a methyl group at the fifth carbon position of cytosine bases located $5^{\prime}$ to a guanosine in a $\mathrm{CpG}$ dinucleotide. Tumor suppressor gene hypermethylation results in gene silencing, occurs at early stages of cancer development, and is easily detected in cfDNA, mostly by methylation-specific PCR technologies (128).

The short stature homeobox 2 gene (SHOX2) is a known chondrocyte hypertrophy regulator, playing important functions in skeleton development, embryogenic pattern formation (129), embryonic morphogenesis, heart and nervous system development (130). SHOX2 methylation was investigated in respiratory $(107,110,113,115)$ and plasma samples $(108,113)$. When considered as a single biomarker, sensitivities for LC detection ranged from 68 to $89 \%$ in respiratory samples (107, $113)$ and from 60 to $81 \%$ in plasma $(108,113)$. Interestingly, SCLC histology presented the highest and stage I patients the lowest sensitivity values $(107,108)$. The performance of the in vitro diagnostic test kit Epi proLung BL Reflex Assay was assessed both in saccomanno-fixed bronchial and blood samples (110, 113). Analyzing SHOX2 and PTGER4 methylation in bronchial aspirates, Dietrich et al. (110) reported 78\% sensitivity and 96\% specificity in discriminating 125 LC cases from 125 controls. Interestingly, the sensitivity was higher in cytology positive samples, suggesting that this test may complement traditional investigations (110). Moreover, when respiratory and plasma samples were considered, the sensitivity increases, suggesting advantages in using a combined approach (113).

Methylation of other candidate genes was proposed for diagnostic biomarker in LC, including RASSF1A (106, 111, 116), HOXA9 (109, 116), Septin 9 (112) and DCLK1 (114). Ponomaryova et al. (111) showed that both RARB2, a tumor suppressor gene that encodes a retinoid acid nuclear receptor, and RASSF1A methylation were increased in stage I-III LC patients both in cfDNA and DNA bound to the blood cells surface. The best performance model reported included RARB2 and RASSF1A, both in plasma and bound to blood cells surface. Yet, the highest accuracy was found among stage III patients (111). SHOX2 (107) (108), HOXA9 (116), RASSF1A (116), and DCLK1 (114) hypermethylations seem to be more frequent among SCLC patients.

\section{Combination Biomarkers}

Combination of biomarkers seems to be a reasonable option to increase the performance of cfDNA methylation as a diagnostic marker. Nikolaidis et al. (121) suggested a set of four genes (TERT, WT1, p16 and RASSF1) to diagnose LC in bronchial lavage samples and, although sensitivity was improved in cytology-positive samples, the assay seems to be particularly useful in diagnosing cytology-negative LC. Interestingly, SCLC and squamous cell carcinomas were more detectable than adenocarcinomas (121). In a study by Ma and colleagues (123), using quantum dots-based (QDs-based) fluorescence resonance energy transfer (FRET) nanosensor technique to identify hypermethylation of a 3-gene panel, including PCDHGB6, HOXA9 and RASSF1, in bronchial brushings, a robust diagnostic performance for early-stage LC was reported, yet, sensitivity varied according to stage and histotype (123). The analysis of sputum samples of participants from the NELSON trial, demonstrated that, while sputum cytology did not detect 
any LC patients, a 3-gene panel, comprising RASSF1A, 3OST2 and PRDM14, detected $28 \%$ of cases 2 years before the diagnosis (126). Hulbert and colleagues (124) investigated subjects with suspicious nodules on CT imaging and built prediction models combining gene methylation with clinical information that correctly predicted LC in $91 \%$ of subjects using sputum and in 85\% using plasma (124). From 20 tumor suppressor genes, Zhang et al. (119) found that nine (APC, CDH13, KLK10, DLEC1, RASSF1A, EFEMP1, SFRP1, RARb and p16INK4A) revealed a higher frequency of hypermethylation in stage I-II NSCLC than in cancer-free plasmas. Additionally, a 5-gene panel, comprising APC, RASSF1A, CDH13, KLK10 and DLEC1 achieved a sensitivity of $84 \%$ and specificity of $74 \%$ for early LC diagnosis (119).

More recently, Liang and collaborators created a plasmabased 9-marker diagnostic model to distinguish malignant from benign nodules, with a sensitivity of $80 \%$ and a specificity of $85 \%$. The model was also very sensitive for early stages, which highlights its utility as complement to imaging methods (127). Interestingly, Ooki and colleagues (125), determined the clinical utility of a set of six genes, including CDO1, HOXA9, AJAP1, PTGDR, UNCX, and MARCH11, for predicting LC diagnosis not only in serum samples but also in pleural effusions and ascites. In serum, the panel reached a specificity of $71 \%$, and a sensitivity of 72 and $60 \%$ for stage IA adenocarcinoma and squamous cell carcinoma, respectively. Promoter methylation of the six genes was significantly higher in cytology-positive pleural effusions and, when methylation of at least one of the four genes (CDO1, PTGDR, MARCH11, and UNCX) was considered, the sensitivity and specificity reached 70 and $85 \%$, respectively. When AJAP1 was added to the panel, sensitivity increases and specificity drops, with similar findings for ascites, suggesting the utility of this gene panel for LC detection using different body fluids (125).

In conclusion, cfDNA concentration in plasma or serum samples seems to have diagnostic value in early-stages LC. As tumors-derived cfDNA is likely to represent the whole cancer genomic landscape, its genetic analysis has shown promising results. However, the genetic alteration or, more probably, a set of genetic changes with optimal diagnostic accuracy is still to be defined. Methylation is an early and frequently found epigenetic alteration that can be detected in cfDNA, not only from plasma or serum samples but also from respiratory specimens and other body fluids, representing an excellent opportunity for LC early diagnosis. Further studies are needed to find the optimal biomarker combination. For example, a single tube liquid biopsy allowing simultaneous analysis of cfDNA, tumor-derived extracellular vesicles and CTC with high and low EpCAM expression proved to be useful in predicting survival among advanced NSCLC (131). In the future, a similar combination biomarker strategy may be employed in diagnostic setting.

\section{Circulating Tumor Cells}

A meta-analysis demonstrated that CTCs detection seems to be associated to lymph nodal metastasis and staging but not to histology (132). Since CTCs are very rare in bloodstream and are surrounded by normal peripheral blood cells, such as mononuclear and red blood cells (33), several techniques have been developed to selectively enrich CTCs and remove other blood cell components. These assays are classified as labeldependent, which includes EpCAM-based technologies (positive selection) and depletion of CD45-positive leukocytes (negative selection), and label-independent approaches, in which CTCs are separated based on CTCs physical or biological properties. The combination of these approaches may be used. After enrichment, CTCs need to be characterized, usually through the identification of tumor-associated proteins, mRNA or DNA, using several strategies that includes fluorescence immunocytochemistry, RT-PCR, next-generation sequencing (NGS) and whole-genome amplification $(33,133)$.

Several studies evaluated the utility of CTCs in diagnosing LC (Table 5). The CellSearch system, an EpCAM-based technology approved by FDA, has been investigated in LC diagnosis. Allard and collaborators studied a population of healthy subjects, nonmalignant diseases, and patients with a variety of metastatic carcinomas, including LC. A cut-off of $\geq 2$ CTCs $/ 7.5 \mathrm{ml}$ blood only identified $20 \%$ of LC patients (134). A prospective study showed that CTCs were detected in $30.6 \%$ of LC and in $12.0 \%$ of non-malignant disease patients and, despite CTC count was significantly higher among the first group, had a low discriminatory capacity (135). However, metastatic and nonmetastatic LC patients were successfully distinguished (135).

Isolation by size of epithelial tumor cell (ISET) has been investigated in LC early diagnosis. In 2011, Hofman et al. (136) reported a mean of 42 circulating nonhematologic cells detected in $49 \%$ of NSCLC patients undergoing surgery, 37\% with malignant features and no cells were found in the control healthy group (136). One year later, the same authors achieved similar conclusions in a larger population (138). Ilie and colleagues (139) examined the presence of CTCs in complement to CT-scan in patients with chronic obstructive pulmonary disease (COPD) in order to identify early LC. CTCs were detected in $5 \%$ of COPD patients and all of them developed LC after a mean follow-up period of 3.2 years, suggesting that monitoring CTC-positive COPD patients may allow early LC diagnosis. Importantly, a study comparing CellSearch and ISET methods in LC diagnosis showed that CTCs can be detected by both methods. Moreover, they may complement each other since the percentage of patients with detected CTCs is higher when combining the two methods with a higher number of CTCs detected by ISET (137). Obstacles to CellSearch method include epithelial-mesenchymal transition phenomena and epithelial nontumor cells in circulation $(133,149)$. Even though CTCs detected by CellSearch are able to predict the prognosis among NSCLC patients reflecting their clinical relevance $(150,151)$.

Anti-cluster of differentiation, CD45 antibody-coated magnetic beads, have been used for leucocyte depletion and negatively enrich CTCs. Although this method has a high sensitivity (152), CTCs and leucocytes may aggregate and form clusters, or even CTCs may be loss in the process (153). $\mathrm{Xu}$ et al. (143) compared this negative enrichment method to an unbiased detection method, in which erythrocytes were lysed and removed and the remaining nucleated cells were bound to substrates, fixed, stained using fluorescence-labeled antibodies 


\begin{tabular}{|c|c|c|c|c|c|c|c|}
\hline \multirow[t]{2}{*}{ Study } & \multirow[t]{2}{*}{ Year } & \multirow[t]{2}{*}{ Assay } & \multirow[t]{2}{*}{ Study population } & \multirow[b]{2}{*}{ Cut-off } & \multicolumn{3}{|c|}{ Diagnostic performance } \\
\hline & & & & & $\mathbf{s}$ & E & AUC \\
\hline Allard (134) & 2005 & CellSearch system & $\begin{array}{l}145 \text { healthy women } \\
199 \text { women with non-malignant disease } \\
964 \text { metastatic cancer patients including } 99 \text { LC }\end{array}$ & $\geq 2 \mathrm{CTCs} / 7.5 \mathrm{ml}$ & $20 \%$ & $99 \%$ & - \\
\hline Tanaka (135) & 2009 & CellSearch system & $\begin{array}{l}25 \text { patients with non-malignant lung disease } \\
125 \text { LC patients ( } 22 \text { SCC, } 85 \text { ADC, } 9 \text { SCLC, } 9 \\
\text { other) } \\
\text { Stages: I-III: 94; IV: } 31\end{array}$ & $\geq 1 \mathrm{CTCs} / 7.5 \mathrm{ml}$ & $30 \%$ & $88 \%$ & 0.598 \\
\hline Hofman (136) & 2011 & ISET method & $\begin{array}{l}39 \text { healthy subjects } \\
208 \text { NSCLC (54 SCC, } 115 \text { ADC, } 39 \text { others) } \\
\text { Stages: I: 86; II: 51; III: 58; IV: } 13\end{array}$ & $\geq 1 \mathrm{CTCs} / \mathrm{ml}$ & $37 \%$ & $100 \%$ & - \\
\hline Hofman (137) & 2011 & CellSearch system vs. ISET method & $\begin{array}{l}40 \text { healthy subjects } \\
210 \text { NSCLC ( } 57 \text { SCC, } 120 \text { ADC, } 33 \text { other) } \\
\text { Stages: I: } 91 \text {; II: 40; III: 60; IV: } 19\end{array}$ & $\geq 1 \mathrm{CTCs} / \mathrm{ml}$ & $\begin{array}{l}\text { ISET: 50\%CellSearch: 39\%Combined: } \\
69 \%\end{array}$ & $100 \%$ & \\
\hline Hofman (138) & 2012 & ISET method & $\begin{array}{l}59 \text { healthy subjects } \\
250 \text { NSCLC patients (67 SCC, } 150 \text { ADC, } 33 \\
\text { others) } \\
\text { Stages: I: } 111 \text {; II: 70; III: 50; IV: } 19\end{array}$ & $\geq 1 \mathrm{CTCs} / \mathrm{ml}$ & $41 \%$ & $100 \%$ & - \\
\hline llie (139) & 2014 & ISET method & $\begin{array}{l}77 \text { non-COPD controls ( } 42 \text { smokers and } 35 \\
\text { healthy } \\
\text { non-smoking individuals) } \\
168 \text { COPD patients }\end{array}$ & $\geq 1 \mathrm{CTCs} / \mathrm{ml}$ & $\begin{array}{l}\text { All COPD patients in which CTCs } \\
\text { were found (5\%) developed LC during } \\
\text { follow-up. }\end{array}$ & $\begin{array}{l}\text { Non-COPD controls: } \\
\text { 100\%COPD controls: } \\
95 \%\end{array}$ & - \\
\hline Dorsey (140) & 2015 & $\begin{array}{l}\text { Telomerase-promoter } \\
\text { immunofluorescence-based assay }\end{array}$ & $\begin{array}{l}\text { Healthy controls } \\
30 \text { NSCLC patients referred for definite RT }\end{array}$ & $\geq 1 \mathrm{CTCs} / \mathrm{ml}$ & $65 \%$ & $100 \%$ & - \\
\hline Fiorelli (141) & 2015 & Isolation by size method & $\begin{array}{l}77 \text { patients with a single lung lesion: } 17 \text { benign } \\
\text { lesions and } 60 \text { with LC (29 ADC, } 18 \text { SCC, } 13 \\
\text { LCC } \\
\text { Stages: I: } 25 \text {; II: 19; III: 10; IV: } 6\end{array}$ & $>25 \mathrm{CTCs} / \mathrm{ml}$ & $89 \%$ & $100 \%$ & 0.900 \\
\hline Chen (142) & 2015 & Ligand-targeted PCR for folate receptors & $\begin{array}{l}56 \text { healthy volunteers } \\
227 \text { patients with benign lung disease } \\
473 \text { NSCLC patients (293 ADC, } 103 \text { SCC, } 77 \\
\text { others) } \\
\text { Stages I: 18; II: 5; III: 127; IV: } 323\end{array}$ & $\geq 1 \mathrm{CTCs} / 3 \mathrm{ml}$ & $76 \%$ & $82 \%$ & 0.813 \\
\hline Xu (143) & 2017 & $\begin{array}{l}\text { Negative enrichment using anti-CD45 } \\
\text { coated magnetic beads and CD45 } \\
\text { depletion cocktail vs unbiased method }\end{array}$ & $\begin{array}{l}151 \text { non-cancerous controls } \\
83 \text { LC patients } \\
\text { Stages: I: } 13 \text {; II: 10; III: 33; IV: } 27\end{array}$ & $\geq 1 \mathrm{CTCs} / \mathrm{ml}$ & $\begin{array}{l}\text { Anti-CD } 45 \text { coated magnetic beads } \\
\text { group: } 62 \% \text { CD } 45 \text { depletion cocktail } \\
\text { group: } 47 \% \text { Unbiased group: } 92 \%\end{array}$ & $94 \%$ & - \\
\hline Xue (144) & 2018 & Ligand-targeted PCR for folate receptors & $\begin{array}{l}24 \text { patients with benign lung diseases and } 2 \\
\text { healthy subjects } \\
72 \text { LC patients ( } 50 \text { ADC, } 14 \text { SCC, } 8 \text { others) } \\
\text { Stages: 0-IS: } 2 \text {; I: 31; II: } 7 \text {; III: 12; IV: 14; } \\
\text { Uncertain: } 6\end{array}$ & $8.7 \mathrm{CTC} / 3 \mathrm{~mL}$ & $82 \%$ & $73 \%$ & 0.822 \\
\hline Frick (145) & 2020 & $\begin{array}{l}\text { Telomerase-promoter } \\
\text { immunofluorescence-based assay }\end{array}$ & $\begin{array}{l}92 \text { NSCLC undergoing SBRT (22 ADC, } 15 \text { SCC, } \\
55 \text { not confirmed) } \\
\text { Stages: IA: 81; IB: } 11\end{array}$ & $\geq 1 \mathrm{CTCs} / \mathrm{ml}$ & $41 \%$ & - & - \\
\hline $\mathrm{He}(146)$ & 2017 & GILUPI CellCollector in vivo & $\begin{array}{l}19 \text { healthy volunteers } \\
32 \text { ground-glass nodules patients } \\
15 \text { advanced LC patients }\end{array}$ & $\geq 1 \mathrm{CTCs} / 7.5 \mathrm{ml}$ & $\begin{array}{l}\text { GGN group: } 16 \% \text { Advanced LC } \\
\text { patients: } 73 \%\end{array}$ & $100 \%$ & - \\
\hline
\end{tabular}




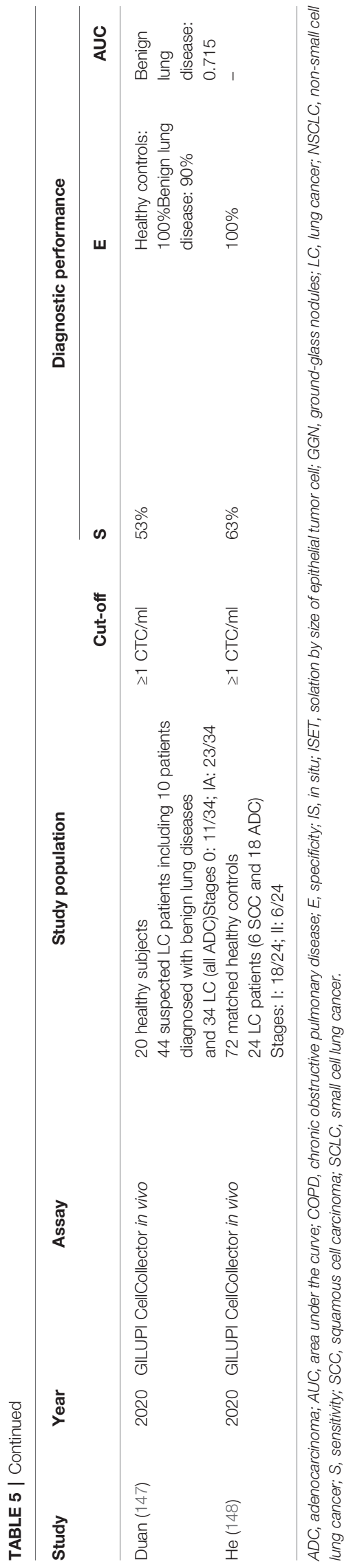

and, thereafter examined by microscopy. The results demonstrated that unbiased detection method efficiently detected $92.2 \%$ of CTCs among LC patients, and $65 \%$ of earlystage LC patients. By contrast, only $40-60 \%$ of CTCs were detected by negative enrichment (143). These results suggest that unbiased detection methods may detect CTCs in early-stage LC patients, also revealing a better sensitivity than negative enrichment methods.

More recently, the diagnostic value of detecting folate receptors (FR)-positive CTC by a novel ligand-targeted polymerase chain reaction method in NSCLC patients was investigated $(154,155)$. Chen and collaborators (142) showed that CTC levels in NSCLC patients were significantly higher than in those with benign lung diseases and in healthy donors. Also, CTC detection was able to identify NSCLC patients (AUC = 0.813). Moreover, a joint model combining CTC, carcinoembryonic antigen, neuron-specific enolase, and Cyfra21-1 was efficient in NSCLC diagnosis (142), showing the interest of combining different types of biomarkers. Later, Xue et al. (142) reported high sensitivity and specificity values using a cut-off value of 8.7 CTC Units $/ 3 \mathrm{ml}$ in discriminating early-stage LC patients from controls (142).

A telomerase-promoter-based assay has shown to be able to overcome the current limitations in detecting CTCs. In a pilot study with 30 patients referred for definite radiotherapy (RT), Dorsay et al. (140) showed a successful detection of CTCs in 65\% of patients, being the median CTC counts in patients before RT significantly higher than post-RT values. Interestingly, one patient was exception and developed metastatic disease soon after RT (140). Also in RT setting, $41 \%$ of early-stage NSCLC patients had a positive CTC test prior to treatment (145).

Other recent approach is the GILUPI CellCollector in vivo examination technique, which consists in a structured and functionalized medical wire that captures CTCs directly from the bloodstream and identifies them through the cytokeratin immunofluorescence intensity signal (156). He and collaborators demonstrated that this strategy was able to identify not only $73.3 \%$ of the ad.vanced LC patients as reported before (157), but also $15.6 \%$ of the ground-glass nodules (146). In two later studies including early LC patients, sensitivity values of $53-63 \%$ were reached $(147,148)$. Remarkably, the captured CTCs can be separated for NGS or PD-L1 analysis (146-148).

Evidence has shown that CTCs are useful as biomarkers in LC diagnosis. However, techniques for CTCs isolation and counting still need to be optimized and harmonized so that can be possible to validate the ideal detection method. New techniques, such as microfluidic technologies have shown exciting results (158). In order to assess technical validity of emerging CTC detection methods and generate comparative data, a platform was recently created to help to define minimal requirements for performance qualification prior to clinical validation (159).

\section{MicroRNAs}

Since miRNA fragments are stable in blood and evidence suggests that their landscape in peripheral circulation correlate with the original tumor (160), they represent a valuable potential biomarker for LC diagnosis. 


\section{Serum and Plasma Samples}

Notable performances in discriminating between LC patients and healthy and/or benign lesions controls were reported by several authors (Table 6.). However, most studies included metastatic and locally advanced patients, and only some of them were restricted to early stages $(168,170,178,185,188)$.

Foss and collaborators demonstrated that miR-1254 and miR-574-5p were significantly increased in serum samples from early-stage NSCLC, achieving a sensitivity and specificity of 73 and $71 \%$, respectively, in differentiating from controls (168). Fan et al. (179) evaluated the miRNA expression in serum samples of NSCLC patients and healthy subjects firstly by qRT-PCR and, thereafter, they validated the results using the fluorescence quantum dots liquid bead array. They found that five miRNAs including miR-16-5p, miR-17b-5p, miR- 19-3p, miR-20a-5p, and miR-92-3p were significantly downregulated, while miR-15b-5p was upregulated among NSCLC patients. A 3miRNA profile (miR-15b-5p, miR-16-5p, miR-20a-5p) using bead array showed to be the best diagnostic approach with high sensitivity and specificity values (179). Both serum and plasma samples from 220 early stage NSCLC patients and 220 matched controls were studied by Heegaard et al. (170) who reported that remarkably the expression levels in serum did not correlate with those in plasma, and while in serum samples from NSCLC patients a decreased expression of miR-146b, miR-221, let-7a, miR-155, miR-17-5p, miR-27a and miR-106a and an increased expression of miR-29c were noticed, no significant differences were stated on miRNAs plasma levels.

More recently, the values of plasma miR-486 and miR-150 for LC early diagnosis were also studied by Li et al. (178). The authors found that, individually, these miRNAs were able to distinguish LC patients from healthy volunteers with reported sensitivity and specificity higher than $80 \%$ (178). A single-center study reported significantly higher levels of miRNA-17, -146a, $-200 \mathrm{~b},-182,-221,-205,-7,-21,-145$, and miRNA-210 in NSCLC nodules comparing with benign ones (185). Later, the same group built a prediction model including 3 miRNAs (miRNA-146a, -200b, and -7) and CT features such as pleural indentation and spiculation, with high diagnostic value in earlystage NSCLC (188).

Circulating miRNAs value in LC screening programs has been widely investigated with promising results. A study by Boeri et al. (167), including participants from two CT-based screening cohorts, INT/IEO and MILD, explored miRNA expression profiles in plasma samples collected from patients 1 and 2 years before CT-detected lesions compared with a control group of heavy-smoking individuals. A signature of 15 miRNAs could discriminate both groups with a sensitivity $80 \%$, and, a specificity of 80 and $90 \%$, respectively (167). Notably, the predictive value of this signature was evaluated to be useful up to 28 months before the disease, with mir-660, mir140-5p, mir 451, mir-28-3p, mir-30c, and mir-92a being the most frequently deregulated miRNAs (167). The most frequently miRNA deregulated at the time of LC diagnosis were mir-17, mir-660, mir-92a, mir-106a, and mir-19b (167). Later, the same research group analyzed the plasma samples from 939 participants, including 69 LC patients and 870 disease-free individuals in two arms (LDCT and observation) and using a miRNA signature classifier comprising 24 miRNAs reported a diagnostic performance for LC detection of $87 \%$ for sensitivity and $81 \%$ for specificity for both arms, and a negative predictive value of $99 \%$ (171). Furthermore, when combined with LDCT, a significant reduction of LDCT false positives was noticed (171). The BioMILD trial (190) consists in a LC screening program combining LDCT and circulating miRNA which prospectively enrolled 4,119 volunteers from a single center. Preliminary analysis presented in IASLC by Pastorino and colleagues showed a higher LC incidence and overall mortality in subjects with positive LDCT and/or miRNA at baseline and no detrimental effects on stage I LC proportion, resection rates, or interval cancer incidence in the group of subjects that completed 3-year LDCT repetition, suggesting that the combination of these tools is a valuable, safe and reduce unnecessary LDCT repeats (191). After Bianchi et al. (169) developed a serum 34 miRNAs panel able to identify patients with NSCLC in an asymptomatic high-risk population. Montani and colleagues (174) performed a multicenter study enrolling 1,115 high-risk individuals from the Continuous Observation of Smoking Subjects (COSMOS) LC screening program and reduced the original serum 34-miRNA signature to 13 miRNAs (miR-92a-3p, miR-30b-5p, miR-191-5p, miR-484, miR-328-3p, miR-30c-5p, miR-374a-5p, let-7d-5p, miR-331-3p, miR-29a-3p, miR-148a-3p, miR-223-3p, miR-140$5 \mathrm{p})$, maintaining the same performance (174).

A systematic review and metanalysis published in 2017 comprising a total of 134 studies, with 6,919 LC patients and 7,064 controls, confirmed the good diagnostic performance of miRNA (192). Moreover, a subgroup analysis showed that combining miRNAs and Caucasian populations yield higher diagnostic performances, serum might serve as an ideal sample type and that the diagnostic role of miRNAs in early stage LC was high (192). Besides, some miRNAs, such as miR-21-5p, miR-223$3 p$, miR-155-5p and miR-126-3p, were pointed out as potential biomarkers (192). A more recent review confirmed the high diagnostic performance of miRNA in early detection of LC and also highlighted that multiple miRNA-based panels generally performed better than individual markers (193).

\section{Respiratory Samples}

Sputum is the most easily accessible biological fluid and its cytological analysis has been used for LC diagnosis despite its low sensitivity. Molecular analysis of sputum might be more sensitive than cytology $(194,195)$. Several studies assessed the role of sputum in diagnosis of LC $(162,163,172,175,180$, 181, 196).

For example, a panel of three sputum miRNAs (miRs-21, 31, and 210) allowed to differentiate between malignant and benign nodules, with sensitivity and specificity values higher than $80 \%$ (175). Additionally, other specifications were explored: overexpression of $m i R-21$ was associated with adenocarcinoma, whereas $m i R-210$ was related to squamous cell carcinoma, and the expression level of $m i R-31$ associated with smoking. These findings suggested that sputum miRNA biomarkers may 


\begin{tabular}{|c|c|c|c|c|c|c|c|c|c|}
\hline \multirow[t]{2}{*}{ Study } & \multirow[t]{2}{*}{ Year } & \multirow[t]{2}{*}{ Assay } & \multirow[t]{2}{*}{ Tested miRNA } & \multirow[t]{2}{*}{ Study population } & \multirow[t]{2}{*}{ Sample } & \multicolumn{4}{|c|}{ Diagnostic performance } \\
\hline & & & & & & Best predictors & & $\mathbf{E}$ & AUC \\
\hline Chen et al. (161) & 2008 & $\begin{array}{l}\text { qRT-PCR } \\
\text { and Solexa } \\
\text { sequencing }\end{array}$ & 63 miRNAs & $\begin{array}{l}75 \text { healthy individuals } \\
152 \text { LC patients }\end{array}$ & Serum & miR-25, miR-223 & - & - & - \\
\hline Xie et al. (162) & 2009 & RT-PCR & $\begin{array}{l}\text { miR-21 and miR- } \\
155\end{array}$ & $\begin{array}{l}17 \text { healthy individuals } \\
23 \text { NSCLC patients (13 ADC and } 10 \text { SCC) } \\
\text { Staging: I: 3; II: 5; III: } 7 ; \text { IV: } 8\end{array}$ & Sputum & miR-21 & $70 \%$ & $100 \%$ & 0.902 \\
\hline Yu et al. (163) & 2010 & RT-PCR & $\begin{array}{l}7 \text { miRNAs (miR- } \\
\text { 486, miR-126, } \\
\text { miR-145, miR-21, } \\
\text { miR-182, miR-375, } \\
\text { and miR-200b) }\end{array}$ & $\begin{array}{l}\text { Discovery set: } 20 \text { stage I ADC } \\
\text { Case-control set: } \\
36 \text { healthy individuals } \\
36 \text { stage I ADC } \\
\text { Validation set: } \\
58 \text { healthy individuals } \\
64 \text { NSCLC patients ( } 33 \text { ADC and } 31 \text { SCC) } \\
\text { Validation set staging: I: } 16 \text {; II: } 15 ; \text { III: } 17 \text {; IV: } 16\end{array}$ & Sputum & $\begin{array}{l}\text { miR-21, miR-486, } \\
\text { miR-375, miR-200b }\end{array}$ & $70 \%$ & $80 \%$ & 0.839 \\
\hline Shen et al. (164) & 2011 & RT-PCR & $\begin{array}{l}12 \text { miRNAs (miR- } \\
21,126,145,139 \\
\text { 182, } 200 b, 205 \\
210,375,429 \\
486-5 p \text {, and } 708 \text { ) }\end{array}$ & $\begin{array}{l}29 \text { healthy individuals } \\
58 \text { NSCLC patients including } 34 \text { ADC and } 24 \text { SCC } \\
\text { Staging: I: 15; II: 15; III: 12; IV: } 16\end{array}$ & Plasma & $\begin{array}{l}\text { miRNA-21, }-126 \\
-210, \text { and } 486-5 p\end{array}$ & $86 \%$ & $97 \%$ & 0.926 \\
\hline Shen et al. (165) & 2011 & RT-PCR & $\begin{array}{l}5 \text { miRNAs (miR-21, } \\
\text { miR126, miR210, } \\
\text { miR375, miR-486- } \\
\text { 5p) }\end{array}$ & $\begin{array}{l}\text { - } 80 \text { benign SPNs patients } \\
\text { - } 76 \text { malignant SPNs patients including } 40 \text { adenocarcinomas } \\
\text { and } 36 \text { squamous cell carcinomas } \\
\text { Staging: I: } 24 \text {; II: } 30 \text {; III-IV: } 22\end{array}$ & Plasma & $\begin{array}{l}\text { miR-21, miR- } 210 \text {, } \\
\text { and miR-486-5p }\end{array}$ & $76 \%$ & $85 \%$ & 0.855 \\
\hline Zheng et al. (166) & 2011 & RT-PCR & $\begin{array}{l}15 \text { miRNAs (miR- } \\
17,-21,-24 \\
-106 a,-125 b \\
-128,-155,-182 \\
-183,-197,-199 b \\
-203,-205,-210 \\
\text { and }-221)\end{array}$ & $\begin{array}{l}68 \text { healthy individuals } \\
74 \text { LC patients: } \\
-17 \text { SCLC } \\
-48 \text { NSCLC (18 ADC, } 23 \text { SCC, } 7 \text { LCC and } 9 \text { others (carcinoid } \\
\text { or mixed tumor) } \\
\text { Staging: I: } 21 \text {; II: } 12 \text {; III: 11; IV: } 30\end{array}$ & Plasma & $\begin{array}{l}\text { miR-155, miR-197, } \\
\text { miR-182 }\end{array}$ & $81 \%$ & $87 \%$ & 0.901 \\
\hline Boeri et al. (167) & 2011 & $\begin{array}{l}\text { TaqMan } \\
\text { Microfluidic } \\
\text { cards }\end{array}$ & 15 miRNAs & $\begin{array}{l}81 \text { heavy smokers' controls } \\
53 \text { LC patients (including } 30 \text { ADC) } \\
\text { Staging: I: } 28 \text {; II-III-IV: } 25\end{array}$ & Plasma & $\begin{array}{l}\text { miR-17, miR-660, } \\
\text { miR-92a, miR-106a, } \\
\text { and miR-19b }\end{array}$ & $75 \%$ & $100 \%$ & 0.880 \\
\hline Foss et al. (168) & 2011 & RT-PCR & $\begin{array}{l}11 \text { miRNAs (miR- } \\
1268, \text { miR-574-5p, } \\
\text { miR-1254, miR- } \\
\text { 1228, miR-297, } \\
\text { miR-1225-5p, miR- } \\
\text { 923, miR-1275, } \\
\text { miR-185, miR-483- } \\
\text { 5p, miR-320a) }\end{array}$ & $\begin{array}{l}\text { Discovery set: } \\
11 \text { healthy individuals; } 11 \text { early-stage (I and II) NSCLC patients } \\
\text { Validation set: } \\
31 \text { healthy individuals; } 22 \text { early-stage (I and II) NSCLC patients }\end{array}$ & Serum & $\begin{array}{l}\mathrm{miR}-1254 \text { and miR- } \\
574-5 p\end{array}$ & $73 \%$ & $71 \%$ & 0.750 \\
\hline Bianchi et al. (169) & 2011 & RT-PCR & 34 miRNAs & $\begin{array}{l}30 \text { healthy individuals } \\
22 \text { ADC } \\
12 \text { SCC } \\
\text { Staging: I: 22; II-IV: } 12\end{array}$ & Serum & - & $71 \%$ & $90 \%$ & 0.890 \\
\hline
\end{tabular}




\begin{tabular}{|c|c|c|c|c|c|c|c|c|c|}
\hline \multirow[t]{2}{*}{ Study } & \multirow[t]{2}{*}{ Year } & \multirow[t]{2}{*}{ Assay } & \multirow[t]{2}{*}{ Tested miRNA } & \multirow[t]{2}{*}{ Study population } & \multirow[t]{2}{*}{ Sample } & \multicolumn{4}{|c|}{ Diagnostic performance } \\
\hline & & & & & & Best predictors & $\mathbf{s}$ & $\mathbf{E}$ & AUC \\
\hline Heegaard et al. (170) & 2012 & RT-PCR & 30 miRNAs & $\begin{array}{l}220 \text { early-stage NSCLC patients } \\
220 \text { healthy individuals } \\
\text { Staging: I: } 180 ; \text {;I: } 40\end{array}$ & Serum & $\begin{array}{l}\text { miR-146b, miR-221, } \\
\text { let-7a, miR-155, miR- } \\
\text { 17-5p, miR27a, miR- } \\
\text { 106a, miR-29c }\end{array}$ & - & - & 0.602 \\
\hline Sozzi et al. (171) & 2014 & RT-PCR & 24 miRNAs & $\begin{array}{l}870 \text { healthy individuals ( } 690 \text { smokers) } \\
69 \text { LC patients ( } 55 \text { smokers) } \\
\text { Staging: I: } 37 \text {; II-III: } 12 \text {; IV: } 19\end{array}$ & Plasma & - & $87 \%$ & $81 \%$ & - \\
\hline Shen et al. (172) & 2014 & RT-PCR & $\begin{array}{l}12 \text { miRNAs (miRs- } \\
21,31,126,139 \\
\text { 182, 200b, 205, } \\
210,375,429 \\
486, \text { and } 708 \text { ) }\end{array}$ & $\begin{array}{l}\text { Training set: } 68 \text { cancer-free smokers; } 66 \text { LC patients ( } 27 \\
\text { ADC, } 26 \text { SCC and } 13 \text { SCLC) } \\
\text { Training set staging of the NSCLC patients: I: } 17 \text {; II: 18; III-IV: } \\
18 \\
\text { Testing set: } 73 \text { cancer-free smokers; } 64 \text { LC patients ( } 30 \text { ADC, } \\
28 \text { SCC, } 6 \text { SCLC) } \\
\text { Testing set staging of the NSCLC patients: I: } 19 \text {; II: 19; III-IV: } \\
20\end{array}$ & Sputum & miR-31, miR-210 & $65 \%$ & $89 \%$ & 0.830 \\
\hline Wang et al. (173) & 2014 & RT-PCR & $\begin{array}{l}9 \text { miRNAs(miR- } \\
20 a \text {, miR-25, miR- } \\
\text { 486-5p, miR-126, } \\
\text { miR-125a-5p, miR- } \\
\text { 205, miR-200b, } \\
\text { miR-21, and miR- } \\
\text { 155) }\end{array}$ & $\begin{array}{l}111 \text { healthy individuals } \\
142 \text { LC patients (including } 101 \text { ADC, } 22 \text { SCC and } 10 \text { SCLC) } \\
\text { Staging: I: 70; II: 24; III: 21; IV: } 27\end{array}$ & Serum & $\begin{array}{l}\text { miR-125a-5p, miR-25, } \\
\text { and miR-126 }\end{array}$ & $88 \%$ & $83 \%$ & 0.930 \\
\hline Montani et al. (174) & 2015 & RT-PCR & 34 miRNAs & $\begin{array}{l}972 \text { healthy individuals } \\
36 \text { LC patients ( } 28 \text { ADC and } 5 \text { SCC) } \\
\text { Staging: I: } 31 ; \text { II-III: } 5\end{array}$ & Serum & $\begin{array}{l}\text { miR-92a-3p, miR- } \\
\text { 30b-5p, miR-191-5p, } \\
\text { miR-484, miR-328-3p, } \\
\text { miR-30c-5p, miR- } \\
\text { 374a-5p, let-7d-5p, } \\
\text { miR-331-3p, miR- } \\
\text { 29a-3p, miR-148a-3p, } \\
\text { miR-223-3p, miR- } \\
\text { 140-5p }\end{array}$ & $75 \%$ & $78 \%$ & 0.850 \\
\hline Xing et al. (175) & 2015 & RT-PCR & $\begin{array}{l}13 \text { miRNAs } \\
\text { (miR205; miR708; } \\
\text { miR375; miR200b; } \\
\text { miR182; miR155; } \\
\text { miR372; miR143; } \\
\text { miR486-5p; } \\
\text { miR126; miR31; } \\
\text { miR21; miR210) }\end{array}$ & $\begin{array}{l}\text { Training set: } 62 \text { benign SPNs; } 60 \text { malignant SPNs (with } 27 \\
\text { ADC and } 29 \text { SCC) } \\
\text { Training set staging: I: } 39 ; \text { II: } 21 \\
\text { Internal Testing set: } 69 \text { benign SPNs; } 67 \text { malignant SPNs } \\
\text { (including } 30 \text { ADC and } 31 \text { SCC) } \\
\text { Internal Testing set staging: I: } 45 ; \text { II: } 22 \\
\text { External Testing set: } 79 \text { benign SPNs; } 76 \text { malignant SPNs } \\
\text { (including } 34 \text { ADC and } 35 \text { SCC) } \\
\text { External Testing set staging: I: } 51 ; \text { II: } 25\end{array}$ & Sputum & $\begin{array}{l}\text { miR-21, miR-31, miR- } \\
210\end{array}$ & $82-88 \%$ & $81-87 \%$ & 0.920 \\
\hline Wang et al. (176) & 2015 & RT-PCR & $\begin{array}{l}16 \text { miRNAs (miR- } \\
\text { 193a-3p, miR-214, } \\
\text { miR-7, miR-25, } \\
\text { miR-483-5p, miR- } \\
\text { 523, miR-885-5p, } \\
\text { miR-520c-3p, miR- }\end{array}$ & $\begin{array}{l}48 \text { healthy individuals } \\
56 \text { benign nodules } \\
108 \text { NSCLC patients (including } 52 \text { ADC and } 27 \text { SCC) } \\
\text { Staging: I: 43; II: } 15 \text {; III: } 29 \text {; IV: } 17\end{array}$ & Serum & $\begin{array}{l}\text { miR-483-5p, miR- } \\
\text { 193a-3p, miR-214, } \\
\text { miR-25, and miR-7 }\end{array}$ & $95 \%$ & $84 \%$ & 0.952 \\
\hline
\end{tabular}




\begin{tabular}{|c|c|c|c|c|c|c|c|c|c|}
\hline \multirow[t]{2}{*}{ Study } & \multirow[t]{2}{*}{ Year } & \multirow[t]{2}{*}{ Assay } & \multirow[t]{2}{*}{ Tested miRNA } & \multirow[t]{2}{*}{ Study population } & \multirow[t]{2}{*}{ Sample } & \multicolumn{4}{|c|}{ Diagnostic performance } \\
\hline & & & & & & Best predictors & $\mathbf{s}$ & $\mathbf{E}$ & AUC \\
\hline & & & $\begin{array}{l}\text { 484, miR-720, } \\
\text { miR-133a, miR- } \\
\text { 337-5p, miR-150, } \\
\text { miR-1274b, miR- } \\
\text { 342-3p, miR-145) }\end{array}$ & & & & & & \\
\hline Kim et al. (177) & 2015 & RT-PCR & $\begin{array}{l}5 \text { miRNAs (miR-21, } \\
\text { miR-143, miR-155, } \\
\text { miR-210, and miR- } \\
\text { 372) }\end{array}$ & $\begin{array}{l}10 \text { cancer-free controls } \\
21 \text { early-stage NSCLC patients ( } 13 \text { ADC, } 5 \text { SCC and } 3 \text { LCC) } \\
\text { Staging: I: } 12 \text {; II: } 9\end{array}$ & $\begin{array}{l}\text { BAL } \\
\text { fluid/ } \\
\text { Sputum }\end{array}$ & $\begin{array}{l}\text { miR-21, miR-143, } \\
\text { miR-155, miR-210, } \\
\text { and miR-372 }\end{array}$ & $\begin{array}{l}\text { Patients BAL } \\
\text { vs controls } \\
\text { sputum: } 86 \% \\
\text { Sputum: } 68 \%\end{array}$ & $\begin{array}{l}\text { Patients BAL } \\
\text { vs controls } \\
\text { sputum: } 100 \% \\
\text { Sputum: } 90 \%\end{array}$ & \\
\hline Li et al. (178) & 2015 & RT-PCR & $\begin{array}{l}10 \text { miRNAs (miR- } \\
126, \text { miR-150, } \\
\text { miR-155, miR-205, } \\
\text { miR-21, miR-210, } \\
\text { miR-26b, miR-34a, } \\
\text { miR-451 and miR- } \\
\text { 486) }\end{array}$ & $\begin{array}{l}11 \text { healthy individuals } \\
11 \text { early-stage NSCLC patients } \\
\text { Staging: I-II: } 11\end{array}$ & Plasma & $\begin{array}{l}\text { miR-486 and miR-150 } \\
\text { (individually) }\end{array}$ & $\begin{array}{l}\text { miR-486: } 91 \% \\
\text { miR-150: } 82 \%\end{array}$ & $\begin{array}{l}\text { miR-486: 82\% } \\
\text { miR-150: 82\% }\end{array}$ & $\begin{array}{l}\text { miR-486: } \\
0.926 \mathrm{miR}-150: \\
0.752\end{array}$ \\
\hline Fan et al. (179) & 2016 & $\begin{array}{l}\text { Fluorescence } \\
\text { quantum } \\
\text { dots liquid } \\
\text { bead }\end{array}$ & $\begin{array}{l}12 \text { miRNAs (miR- } \\
15 b-5 p, \text { miR-16- } \\
\text { 5p, miR-17b-5p, } \\
\text { miR-19-3p, miR- } \\
\text { 20a-5p, miR-28- } \\
\text { 3p, miR-92-3p, } \\
\text { miR-106-5p, miR- } \\
\text { 146-3p, miR-506, } \\
\text { miR-579, and miR- } \\
664\end{array}$ & $\begin{array}{l}54 \text { healthy individuals } \\
70 \text { NSCLC patients ( } 56 \text { ADC, } 12 \text { SCC and } 2 \text { LCC) } \\
\text { Staging: I: 49; II-III: } 21\end{array}$ & Serum & $\begin{array}{l}\text { miR-15b-5p, miR-16- } \\
5 p \text {, miR-20a-5p }\end{array}$ & $94 \$$ & $94 \%$ & 0.930 \\
\hline Razzak et al. (180) & 2016 & RT-PCR & $\begin{array}{l}3 \text { miRNAs (miR-21, } \\
\text { miR-210, miR-372) }\end{array}$ & $\begin{array}{l}10 \text { healthy individuals } \\
21 \text { Early-stage NSCLC patients (including } 13 \text { ADC and } 4 \text { SCC) } \\
22 \text { Advanced-stage NSCLC patients (10 ADC and } 5 \text { SCC) } \\
\text { Staging: I: 14; II: 7; III: 14; IV: } 8\end{array}$ & Sputum & $\begin{array}{l}\text { miR-21, miR-210, } \\
\text { miR-372 }\end{array}$ & $67 \%$ & $90 \%$ & 0.926 \\
\hline Bagheri et al. (181) & 2017 & RT-PCR & $\begin{array}{l}6 \text { miRNAs (miR- } \\
223, \text { miR-212, } \\
\text { miR-192, miR- } \\
\text { 3074, SNORD33 } \\
\text { and SNORD37) }\end{array}$ & $\begin{array}{l}17 \text { healthy individuals } \\
17 \text { NSCLC patients (11 ADC and } 6 \text { SCC) } \\
\text { Staging: I: } 2 \text {; II: } 3 ; \text { III: } 5 ; \text { IV: } 7\end{array}$ & Sputum & miR-223 & $82 \%$ & $95 \%$ & 0.900 \\
\hline Leng et al. (182) & 2017 & RT-PCR & 54 miRNAs & $\begin{array}{l}30 \text { cancer-free smokers } \\
34 \text { NSCLC patients (21 AC and } 13 \text { SCC) } \\
\text { Staging: I: 19; II: 9; III-IV: } 15\end{array}$ & Plasma & $\begin{array}{l}\text { miRs-126, 145, 210, } \\
\text { and 205-5p }\end{array}$ & $92 \%$ & $97 \%$ & 0.960 \\
\hline Lu et al. (183) & 2018 & RT-PCR & $\begin{array}{l}13 \text { miRNAs (miR- } \\
\text { 101, miR-133a, } \\
\text { miR-17,miR-190b, } \\
\text { miR-19a, miR-19b, } \\
\text { miR-205, miR-26b, } \\
\text { miR-375, miR-451, } \\
\text { miR-601, miR-760, } \\
\text { miR-765) }\end{array}$ & $\begin{array}{l}203 \text { normal individuals } \\
258 \text { LC patients (133 ADC, } 76 \text { SCC and } 49 \text { SCLC) } \\
\text { Staging: I: } 78 \text {; II: } 27 \text {; III: 40; IV: } 64\end{array}$ & Plasma & $\begin{array}{l}\text { miR-17, miR-190b, } \\
\text { miR-19a, miR-19b, } \\
\text { miR-26b, and miR- } \\
375\end{array}$ & $80 \%$ & $80 \%$ & 0.868 \\
\hline
\end{tabular}




\begin{tabular}{|c|c|c|c|c|c|c|c|c|c|}
\hline \multirow[t]{2}{*}{ Study } & \multirow[t]{2}{*}{ Year } & \multirow[t]{2}{*}{ Assay } & \multirow[t]{2}{*}{ Tested miRNA } & \multirow[t]{2}{*}{ Study population } & \multirow[t]{2}{*}{ Sample } & \multicolumn{4}{|c|}{ Diagnostic performance } \\
\hline & & & & & & Best predictors & s & E & AUC \\
\hline $\begin{array}{l}\text { Abu-Duhier et al. } \\
\text { (184) }\end{array}$ & 2018 & $\begin{array}{l}\text { Magnetic } \\
\text { bead } \\
\text { technology } \\
\text { and TaqMan } \\
\text { assays }\end{array}$ & miRNA-21 & $\begin{array}{l}80 \text { healthy individuals } \\
80 \text { NSCLC patients ( } 60 \text { ADC and } 20 \text { SCC) } \\
\text { Staging: I: 2; II: 7; III: } 26 \text {; IV: } 46\end{array}$ & Plasma & - & $80 \%$ & $80 \%$ & 0.891 \\
\hline Xi et al. (185) & 2018 & RT-PCR & $\begin{array}{l}12 \text { miRNAs } \\
\text { (miRNA-17, -146a, } \\
-200 b,-182,-155 \text {, } \\
-221,-205,-126 \text {, } \\
-7,-21,-145 \text {, and } \\
\text { miRNA-210) }\end{array}$ & $\begin{array}{l}15 \text { benign pulmonary nodules } \\
42 \text { NSCLC patients } \\
\text { Staging: IA: 29; IB: } 10 ; 11: 3\end{array}$ & Plasma & $\begin{array}{l}\text { miRNA-17, }-146 a \\
-200 b,-182,-221 \\
-205,-7,-21,-145 \\
-210 \text { (individually) }\end{array}$ & $>55 \%$ & $>60 \%$ & $>0.680$ \\
\hline Li et al. (186) & 2019 & RT-PCR & $\begin{array}{l}4 \text { miRNAs (miRs- } \\
126-3 p, 145,210- \\
3 p \text { and } 205-5 p)\end{array}$ & $\begin{array}{l}245 \text { cancer-free smokers } \\
239 \text { NSCLC cases (111 AC, } 102 \text { SCC and } 26 \text { LCC) } \\
\text { Staging: I: 72; II: 76; III-IV: } 91\end{array}$ & Plasma & $\begin{array}{l}\text { miRs-126-3p, 145, } \\
210-3 p \text { and 205-5p }\end{array}$ & $90 \%$ & $95 \%$ & - \\
\hline Liang et al. (187) & 2019 & RT-PCR & miRNA-30a-5p & $\begin{array}{l}20 \text { healthy individuals } \\
38 \text { lung benign lesions104 LC patients (including } 75 \text { ADC, } 20 \\
\text { SCC and } 5 \text { SCLC) } \\
\text { Staging: I-IIA: 62; IIB-IV: } 42\end{array}$ & Plasma & - & $80 \%$ & $61 \%$ & 0.820 \\
\hline Xi et al. (188) & 2019 & RT-PCR & $\begin{array}{l}10 \text { miRNAs (miR- } \\
17,-146 a,-200 b \\
-182,-221,-205 \\
-7,-21,-145 \text {, and } \\
\text { miR-210) }\end{array}$ & $\begin{array}{l}13 \text { benign pulmonary nodules } \\
39 \text { NSCLC patients } \\
\text { staging: 0-IA: } 31 ; \text { IB: } 7 ; \text { IIA: } 1\end{array}$ & Plasma & $\begin{array}{l}\text { miRNA-146a, -200b, } \\
\text { and }-7\end{array}$ & $72 \%$ & $69 \%$ & 0.781 \\
\hline Liao et al. (189) & 2020 & RT-PCR & $\begin{array}{l}2 \text { miRNAs in } \\
\text { sputum (miRs-31- } \\
5 p \text { and } 210-3 p) 3 \\
\text { miRNAs in plasma } \\
\text { (miRs-21-5p, 210- } \\
3 p \text {, and 486-5p) }\end{array}$ & $\begin{array}{l}55 \text { cancer-free smokers } \\
56 \text { NSCLC patients ( } 31 \text { ADC and } 25 \text { SCC) } \\
\text { Staging: I: 18; II: 17; III-IV: } 21\end{array}$ & $\begin{array}{l}\text { Plasma } \\
\text { and } \\
\text { Sputum }\end{array}$ & $\begin{array}{l}\text { Sputum: miRs-31-5p } \\
\text { and } 210-3 p P l a s m a: \\
\text { miRs-21-5p }\end{array}$ & $84 \%$ & $91 \%$ & 0.930 \\
\hline
\end{tabular}

ADC, adenocarcinoma; AUC, area under the curve; BAL, bronchoalveolar lavage; E, specificity; LC, lung cancer; NSCLC, non-small cell lung cancer; RT-PCR, real time polymerase chain reaction; S, sensitivity; SCC, squamous cell carcinoma; SCLC, small cell lung cancer; SPN, solitary pulmonary nodules. 
improve LC screening in heavy smokers (175). Also, the same research group showed that a panel of four miRNAs ( $m i R-21$, $m i R-486, m i R-375$, and $m i R-200 b$ ) could distinguished LC patients from controls with high sensitivities and specificity values, without differences among the stage subgroups, with the best prediction for adenocarcinoma (196).

Indeed, CT scan has an important role in LC diagnosis, however with low specificity. Sheng et al. (172) determine whether analysis of the miRNA signatures could improve regular CT scan and concluded that a panel of two miRNAs could cover the major histological types. Taken together, the combination of miRNA biomarkers and CT provided a higher specificity than CT alone (172).

Showing that respiratory samples other than sputum may have value, Kim and collaborators (177) investigated the role of 5 miRNAs (miR-21, miR-143, miR-155, miR-210, and miR-372) in discriminate early NSCLC patients from controls using both sputum and BAL samples and reported better diagnostic performance with BAL (177). Very recently, Liao et al. (189) determined a higher expression level of two sputum miRNAs (miRs-31-5p and 210-3p) and three plasma miRNAs ( $m i R s-21$ $5 p, 210-3 p$, and 486-5p) of 76 NSCLC patients and 72 cancer-free smokers. Considered these panels, the authors reported 65.875.0\% sensitivities and $83.3-87.5 \%$ specificities for LC diagnosis (189). Moreover, the expression levels of both $m i R-21-5 p$ and $m i R-210-3 p$ in sputum was correlated to squamous cell carcinoma (189). These results suggest that the combination of markers from different body fluids may play a role.

Overall, it seems that some miRNAs, either in circulation or in respiratory samples, have a role as biomarkers for early cancer diagnosis, especially when used in combination and as a complement to LDCT. However, the current data consist mostly in small sized populations from single-center studies with a great variability in terms of staging, analyzed miRNA and methodologies. Despite the great potential of miRNA, larger validation studies are required in order to define their exact role in clinics.

\section{Exosomes}

Exosomes were found to be increased in LC patients compared with healthy controls (197). Several techniques have been used for exosome isolation, including methods based on physical features, such as ultracentrifugation, density gradient separation, ultrafiltration, size exclusion chromatography, chemical precipitation methods, and biological assays such as immune-bead isolation. Transmission electron microscopy and western blot are two examples of frequently used techniques for further exosome characterization. Additionally, commercial kits are available (54).

Exosomal miR-21 is a potential biomarker for cancer diagnosis, including LC. However, may be increased in other types of cancer, as well as in other diseases which suggests that the combination of miRNA panels may provide better results (24). In an early study, Cazzoli et al. (198) reported that a panel of six exosomal miRNAs (miR-151a-5p, miR-30a-3p, miR-200b5p, miR-629, miR-100 and miR-154-3p) were able to discriminate LC from granuloma patients, with a sensitivity and specificity of 96 and 60\%, respectively (AUC $=0.760$ ) (198). Another 6-miRNA panel comprising miR-19b3p, miR21-5p, miR-221-3p, miR-409-3p, miR-425-5p and miR-584-5p was able to discriminate lung adenocarcinoma patients from healthy controls, achieving an AUC of 0.84 (199). Likewise, Jin et al. (200) selected a panel of exosomal miRNAs (let-7b-5p, let$7 e-5 p, m i R-23 a-3 p$ and miR-486-5p) and obtained a sensitivity of $80 \%$ and a specificity of $92 \%$ (AUC $=0.899$ ), regarding ability to differentiate early-stage NSCLC from non-NSCLC patients. Moreover, adenocarcinoma and squamous cell carcinoma histology was identified by combining miR-181b-5p with miR361b-5p (AUC = 0.936), and miR-10b-5p with miR-320b $($ AUC $=0.911)$, respectively $(200)$. Also exosomes might be useful in identified malignant pleural effusions. Lin et al. (201) demonstrated a higher expression of miR-205p5p and miR-200b in pleural effusions of LC patients comparing with those with infections (201). Exosomes may be also useful in identifying tumor somatic mutations, such as EGFR activating mutations $(202,203)$. In addition, some studies have explored the potential of exosomal proteins as diagnostic biomarkers (204-207). More recently, Zhang and colleagues (208) demonstrated that a four biomarker panel, including miR-17-5p, carcinoembryonic antigen (CEA), cytokeratin 19 fragment (CYFRA21-1), and squamous cell carcinoma antigen (SCCA), was able to reach an adequate diagnostic performance (AUC $=0.844)(208)$.

These data suggest that exosomes, specially exosomal miRNAs, due to its stability, may represent valuable diagnostic biomarkers achieving promising sensitivity and specificity results. Although some technical concerns have been raised (209), the technological advances have the potential to overcome these difficulties and to allow the development of more robust assays to be part of the routine clinical practice in the future.

\section{Tumor-Educated Platelets}

Evidence have shown that platelet RNA profile is distinct in patients with and without cancer, the later expressing a highly dynamic mRNA repertoire both at cancer onset and progression as well as during the treatment $(25,210)$. Best et al. (210) prospectively characterized the platelet mRNA profiles in 55 healthy donors and 228 patients with localized and metastasized tumors and concluded that cancer patients could be discriminated from non-cancer individuals with $97 \%$ sensitivity, 94\% specificity and 96\% accuracy (AUC $=0.986$ ). In a multiclass analysis, the authors further distinguished healthy donors from patients with specific types of cancer with an average accuracy of 71\% (210). Biomarkers like KRAS, EGFR, MET, HER2 or PIK3CA were also accurately distinguished using surrogate TEP mRNA profiles (210) as well as EML4-ALK rearrangements (211).Other studies have also shown that the analysis of mRNA profiles may allow to detect the primary tumor (212-214). Also, susceptibility to metastasis and staging seems to be possible to predict (25). Calverley et al. (215) identified a subset of platelet-based gene expression that are differentially expressed in individuals with LC metastases (215).

TEPs may have advantages over other blood-based biosources: they are abundant, may be easily isolated and 
acquire specific RNA from tumor cells. Since platelets have a median of 7 days of survival, expression of a highly dynamic mRNA repertoire is expected during cancer progression. However, more robust and specific studies are needed to better define the value of TEPs applicability in LC early detection, alone or in combination with other blood-based biomarkers or diagnostic procedures.

\section{FUTURE PERSPECTIVES}

While liquid biopsy-derived biomarkers have shown promising results in the early detection of LC, currently, there is no evidence for its use in the screening or diagnosis of LC outside the research setting. These biomarkers are still limited by a significant proportion of false negatives and a negative plasma test still requires a confirmatory tissue biopsy. Indeed, low or absent values of most liquid biopsy components in the very early stages of LC limit their applicability. Due to tumour heterogeneity, to the emergence of different tumours or precancerous conditions and using conventional tissue biopsy as a reference, positive results not related with LC can also be expected, and their clinical significance needs further clarification. The technological advances expected to happen in the next few years may be able to help mitigate these limitations, with the development of more sensitive and specific assays. Biomarker combination and the combined use of biomarkers and other diagnostic tools, such as imaging techniques, seem to be a promising strategy, although the best

\section{REFERENCES}

1. World Health Organization. Global Cancer Observatory. Int Agency Res Cancer (2020).

2. Walters S, Maringe C, Coleman MP, Peake MD, Butler J, Young N, et al. Lung cancer survival and stage at diagnosis in Australia, Canada, Denmark, Norway, Sweden and the UK: a population-based study, 2004-2007. Thorax (2013) 68:551-64. doi: 10.1136/thoraxjnl-2012-202297

3. Bannister N, Broggio J. Cancer survival by stage at diagnosis for England (experimental statistics): Adults diagnosed 2012, 2013 and 2014 and followed up to 2015. Off Natl Stat (2016): 1-30.

4. Pérez-Ramírez C, Cañadas-Garre M, Robles AI, Molina MÁ, Faus-Dáder MJ, Calleja-Hernández MÁ. Liquid biopsy in early stage lung cancer. Transl Lung Cancer Res (2016) 5:517-24. doi: 10.21037/tlcr.2016.10.15

5. Aberle DR, Adams AM, Berg CD, Black WC, Clapp JD, Fagerstrom RM. The National Lung Screening Trial Research Team. Reduced Lung-Cancer Mortality with Low-Dose Computed Tomographic Screening. N Engl J Med (2011) 365:395-409. doi: 10.1056/NEJMoa1102873

6. Team TNLSTR. Lung Cancer Incidence and Mortality with Extended Follow-up in the National Lung Screening Trial. J Thorac Oncol (2019) 14:1732-42. doi: 10.1016/j.jtho.2019.05.044

7. Patz EFJr, Pinsky P, Gatsonis C, Sicks JD, Kramer BS, Tammemägi MC, et al. Team for the NOMW. Overdiagnosis in Low-Dose Computed Tomography Screening for Lung Cancer. JAMA Intern Med (2014) 174:269-74. doi: 10.1001/jamainternmed.2013.12738

8. Richardson CM, Pointon KS, Manhire AR, Macfarlane JT. Percutaneous lung biopsies: A survey of UK practice based on 5444 biopsies. Br J Radiol (2002) 75(897):731-5. doi: 10.1259/bjr.75.897.750731

9. Robertson EG, Baxter G. Tumour seeding following percutaneous needle biopsy: The real story! Clin Radiol (2011) 66(11):1007-14. doi: 10.1016/ j.crad.2011.05.012 combinations are still to be defined. Larger and more robust studies are required to define and validate the role of liquid biopsy in the mainstream clinical practice for the screening or diagnosis of LC.

\section{AUTHOR CONTRIBUTIONS}

All authors listed have made a substantial, direct, and intellectual contribution to the work and approved it for publication.

\section{FUNDING}

This work is financed by the ERDF-European Regional Development Fund through the Operational Programme for Competitiveness and Internationalization-COMPETE 2020 Programme and by National Funds through the Portuguese funding agency, FCT-Fundação para a Ciência e a Tecnologia within project POCI-01-0145-FEDER-030263.

\section{ACKNOWLEDGMENTS}

Authors thank Abilio Cunha and Francisco Correia for the illustration work. NC-M acknowledges the Portuguese Foundation for Science and Technology under Horizon 2020 Program (PTDC/PSI-GER/28076/2017).

10. Rivera MP, Mehta AC, Wahidi MM. Establishing the Diagnosis of Lung Cancer. Chest (2013) 143(5):e142S-65S. doi: 10.1378/chest.12-2353

11. Stahl D, Richard K, Papadimos T. Complications of bronchoscopy: A concise synopsis. Int J Crit Illn Inj Sci (2015) 5(3):189-95. doi: 10.4103/ 2229-5151.164995

12. Bambury RM, Power DG, O'Reilly S. Intratumor heterogeneity and branched evolution [4]. N Engl J Med (2012) 366:2132-3. doi: 10.1056/ NEJMc1204069

13. Definitions B, Group W, Atkinson AJJ, Colburn WA, DeGruttola VG, DeMets DL, et al. Biomarkers and surrogate endpoints: preferred definitions and conceptual framework. Clin Pharmacol Ther (2001) 69:8995. doi: $10.1067 / \mathrm{mcp} .2001 .113989$

14. Wang J, Chang S, Li G, Sun Y. Application of liquid biopsy in precision medicine: opportunities and challenges. Front Med (2017) 11:522-7. doi: 10.1007/s11684-017-0526-7

15. Bardelli A, Pantel K. Liquid Biopsies, What We Do Not Know (Yet). Cancer Cell (2017) 31:172-9. doi: 10.1016/j.ccell.2017.01.002

16. Marques JF, Junqueira-Neto S, Pinheiro J, Machado JC, Costa JL. Induction of apoptosis increases sensitivity to detect cancer mutations in plasma. Eur J Cancer (2020) 127:130-8. doi: 10.1016/j.ejca.2019.12.023

17. Bettegowda C, Sausen M, Leary RJ, Kinde I, Wang Y, Agrawal N, et al. Detection of circulating tumor DNA in early- and late-stage human malignancies. Sci Transl Med (2014) 6:224ra24-224ra24. doi: 10.1126/ scitranslmed.3007094

18. Abbosh C, Birkbak N, Swanton C. Early stage NSCLC - challenges to implementing ctDNA-based screening and MRD detection. Nat Rev Clin Oncol (2018) 15:577-86. doi: 10.1038/s41571-018-0058-3

19. Chemi F, Rothwell DG, McGranahan N, Gulati S, Abbosh C, Pearce SP, et al. Pulmonary venous circulating tumor cell dissemination before tumor resection and disease relapse. Nat Med (2019) 25:1534-9. doi: 10.1038/ s41591-019-0593-1 
20. Kapeleris J, Kulasinghe A, Warkiani ME, Vela I, Kenny L, O’Byrne K, et al. The Prognostic Role of Circulating Tumor Cells (CTCs) in Lung Cancer. Front Oncol (2018) 8:311:311. doi: 10.3389/fonc.2018.00311

21. Siravegna G, Marsoni S, Siena S, Bardelli A. Integrating liquid biopsies into the management of cancer. Nat Rev Clin Oncol (2017) 14:531-48. doi: $10.1038 /$ nrclinonc.2017.14

22. Rijavec E, Coco S, Genova C, Rossi G, Longo L, Grossi F. Liquid Biopsy in Non-Small Cell Lung Cancer: Highlights and Challenges. Cancers (2020) 12:1-17. doi: $10.3390 /$ cancers 12010017

23. Cui S, Cheng Z, Qin W, Jiang L. Exosomes as a liquid biopsy for lung cancer. Lung Cancer (2018) 116:46-54. doi: 10.1016/j.lungcan.2017.12.012

24. Shi J. Considering Exosomal miR-21 as a Biomarker for Cancer. J Clin Med (2016) 5:42. doi: $10.3390 / \mathrm{jcm} 5040042$

25. Lomnytska M, Pinto R, Becker S, Engström U, Gustafsson S, Björklund C, et al. Platelet protein biomarker panel for ovarian cancer diagnosis. Biomark Res (2018) 6:2. doi: 10.1186/s40364-018-0118-y

26. Chen R, Xu X, Qian Z, Zhang C, Niu Y, Wang Z, et al. The biological functions and clinical applications of exosomes in lung cancer. Cell Mol Life Sci (2019) 76:4613-33. doi: 10.1007/s00018-019-03233-y

27. Bettegowda C, Sausen M, Leary R, Kinde I, Agrawal N, Bartlett B, et al. Detection of circulating tumor DNA in early- and late-stage human malignancies. Sci Transl Med (2014) 6:224ra24. doi: 10.1126/ scitranslmed.3007094.Detection

28. Jiang P, Lo YMD. The Long and Short of Circulating Cell-Free DNA and the Ins and Outs of Molecular Diagnostics. Trends Genet (2016) 32:360-71. doi: 10.1016/j.tig.2016.03.009

29. Choi J-J, Reich 3CF, Pisetsky DS. The role of macrophages in the in vitro generation of extracellular DNA from apoptotic and necrotic cells. Immunology (2005) 115:55-62. doi: 10.1111/j.1365-2567.2005.02130.x

30. Thierry AR, El Messaoudi S, Gahan PB, Anker P, Stroun M. Origins, structures, and functions of circulating DNA in oncology. Cancer Metastasis Rev (2016) 35:347-76. doi: 10.1007/s10555-016-9629-x

31. Rykova EY, Morozkin ES, Ponomaryova AA, Loseva EM, Zaporozhchenko IA, Cherdyntseva NV, et al. Cell-free and cell-bound circulating nucleic acid complexes: mechanisms of generation, concentration and content. Expert Opin Biol Ther (2012) 12:S141-53. doi: 10.1517/14712598.2012.673577

32. Ponomaryova AA, Rykova EY, Cherdyntseva NV, Skvortsova TE, Cherepanova AV, Morozkin ES, et al. Concentration and Distribution of Single-Copy $\beta$-Actin Gene and LINE-1 Repetitive Elements in Blood of Lung Cancer Patients BT2010. In: Circulating Nucleic Acids in Plasma and Serum. Dordrecht: Springer Netherlands (2010). p. 41-5.

33. Joosse SA, Gorges TM, Pantel K. Biology, detection, and clinical implications of circulating tumor cells. EMBO Mol Med (2015) 7:1-11. doi: 10.15252/ emmm. 201303698

34. Joosse SA, Pantel K. Biologic challenges in the detection of circulating tumor cells. Cancer Res (2013) 73:8-11. doi: 10.1158/0008-5472.can-12-3422

35. Friedl P, Alexander S. Cancer Invasion and the Microenvironment: Plasticity and Reciprocity. Cell (2011) 147:992-1009. doi: 10.1016/j.cell.2011.11.016

36. Förnvik D, Andersson I, Dustler M, Ehrnström R, Rydén L, Tingberg A, et al. No evidence for shedding of circulating tumor cells to the peripheral venous blood as a result of mammographic breast compression. Breast Cancer Res Treat (2013) 141:187-95. doi: 10.1007/s10549-013-2674-z

37. Thiery JP. Epithelial-mesenchymal transitions in tumour progression. Nat Rev Cancer (2002) 2:442-54. doi: 10.1038/nrc822

38. Mimeault M, Batra SK. Molecular biomarkers of cancer stem/progenitor cells associated with progression, metastases, and treatment resistance of aggressive cancers. Cancer Epidemiol Biomarkers Prev (2014) 23:234-54. doi: 10.1158/1055-9965.EPI-13-0785

39. Tamminga M, de Wit S, van de Wauwer C, van den Bos H, Swennenhuis JF, Klinkenberg TJ, et al. Analysis of Released Circulating Tumor Cells During Surgery for Non-Small Cell Lung Cancer. Clin Cancer Res (2020) 26:165666. doi: 10.1158/1078-0432.CCR-19-2541

40. Reymond N, d'Água BB, Ridley AJ. Crossing the endothelial barrier during metastasis. Nat Rev Cancer (2013) 13:858-70. doi: 10.1038/nrc3628

41. Uhr JW, Pantel K. Controversies in clinical cancer dormancy. Proc Natl Acad Sci USA (2011) 108:12396-400. doi: 10.1073/pnas.1106613108

42. Esquela-Kerscher A, Slack FJ. Oncomirs - microRNAs with a role in cancer. Nat Rev Cancer (2006) 6:259-69. doi: 10.1038/nrc1840
43. Lim LP, Lau NC, Garrett-Engele P, Grimson A, Schelter JM, Castle J, et al. Microarray analysis shows that some microRNAs downregulate large numbers of target mRNAs. Nature (2005) 433:769-73. doi: 10.1038/nature03315

44. Krek A, Grün D, Poy MN, Wolf R, Rosenberg L, Epstein EJ, et al. Combinatorial microRNA target predictions. Nat Genet (2005) 37:495500. doi: $10.1038 /$ ng1536

45. Bartel DP. MicroRNAs: Genomics, Biogenesis, Mechanism, and Function. Cell (2004) 116:281-97. doi: 10.1016/S0092-8674(04)00045-5

46. Calin GA, Croce CM. MicroRNA-Cancer Connection: The Beginning of a New Tale. Cancer Res (2006) 66:7390-4. doi: 10.1158/0008-5472.CAN-060800

47. Calin GA, Croce CM. MicroRNA signatures in human cancers. Nat Rev Cancer (2006) 6:857-66. doi: 10.1038/nrc1997

48. Schwarzenbach H, Nishida N, Calin GA, Pantel K. Clinical relevance of circulating cell-free microRNAs in cancer. Nat Rev Clin Oncol (2014) 11:145-56. doi: 10.1038/nrclinonc.2014.5

49. Mathivanan S, Ji H, Simpson RJ. Exosomes: Extracellular organelles important in intercellular communication. J Proteomics (2010) 73:190720. doi: $10.1016 /$ j.jprot.2010.06.006

50. Raposo G, Stoorvogel W. Extracellular vesicles: exosomes, microvesicles, and friends. J Cell Biol (2013) 200:373-83. doi: 10.1083/jcb.201211138

51. Reclusa P, Taverna S, Pucci M, Durendez E, Calabuig S, Manca P, et al. Exosomes as diagnostic and predictive biomarkers in lung cancer. J Thorac Dis (2017) 9:S1373-82. doi: 10.21037/jtd.2017.10.67

52. Andre F, Schartz NEC, Movassagh M, Flament C, Pautier P, Morice P, et al. Malignant effusions and immunogenic tumour-derived exosomes. Lancet (2002) 360:295-305. doi: 10.1016/S0140-6736(02)09552-1

53. Azmi AS, Bao B, Sarkar FH. Exosomes in cancer development, metastasis, and drug resistance: a comprehensive review. Cancer Metastasis Rev (2013) 32:623-42. doi: 10.1007/s10555-013-9441-9

54. Zhang X, Yuan X, Shi H, Wu L, Qian H, Xu W. Exosomes in cancer: small particle, big player. J Hematol Oncol (2015) 8:83. doi: 10.1186/s13045-0150181-x

55. Franco AT, Ware J. G Soff, editor. Thrombosis and Hemostasis in Cancer. Cham: Springer International Publishing (2019). p. 37-54. doi: 10.1007/9783-030-20315-3_3

56. Liu L, Lin F, Ma X, Chen Z, Yu J. Tumor-educated platelet as liquid biopsy in lung cancer patients. Crit Rev Oncol Hematol (2020) 146:102863. doi: 10.1016/j.critrevonc.2020.102863

57. Janowska-Wieczorek A, Wysoczynski M, Kijowski J, Marquez-Curtis L, Machalinski B, Ratajczak J, et al. Microvesicles derived from activated platelets induce metastasis and angiogenesis in lung cancer. Int $J$ Cancer (2005) 113:752-60. doi: 10.1002/ijc.20657

58. Gay LJ, Felding-Habermann B. Contribution of platelets to tumour metastasis. Nat Rev Cancer (2011) 11:123-34. doi: 10.1038/nrc3004

59. Jiang X, Wong KHK, Khankhel AH, Zeinali M, Reategui E, Phillips MJ, et al. Microfluidic isolation of platelet-covered circulating tumor cells. Lab Chip (2017) 17:3498-503. doi: 10.1039/c7lc00654c

60. Placke T, Örgel M, Schaller M, Jung G, Rammensee H-G, Kopp H-G, et al. Platelet-Derived MHC Class I Confers a Pseudonormal Phenotype to Cancer Cells That Subverts the Antitumor Reactivity of Natural Killer Immune Cells. Cancer Res (2012) 72:440-8. doi: 10.1158/0008-5472.CAN11-1872

61. Menter DG, Kopetz S, Hawk E, Sood AK, Loree JM, Gresele P, et al. Platelet "first responders" in wound response, cancer, and metastasis. Cancer Metastasis Rev (2017) 36:199-213. doi: 10.1007/s10555-017-9682-0

62. Plantureux L, Crescence L, Dignat-George F, Panicot-Dubois L, Dubois C. Effects of platelets on cancer progression. Thromb Res (2018) 164:S40-7. doi: 10.1016/j.thromres.2018.01.035

63. Labelle M, Begum S, Hynes RO. Direct signaling between platelets and cancer cells induces an epithelial-mesenchymal-like transition and promotes metastasis. Cancer Cell (2011) 20:576-90. doi: 10.1016/j.ccr.2011.09.009

64. Pinedo HM, Verheul HMW, D'Amato RJ, Folkman J. Involvement of platelets in tumour angiogenesis? Lancet (1998) 352:1775-7. doi: 10.1016/ S0140-6736(98)05095-8

65. Cross MJ, Claesson-Welsh L. FGF and VEGF function in angiogenesis: signalling pathways, biological responses and therapeutic inhibition. Trends Pharmacol Sci (2001) 22:201-7. doi: 10.1016/S0165-6147(00)01676-X 
66. Nilsson RJA, Balaj L, Hulleman E, van Rijn S, Pegtel DM, Walraven M, et al. Blood platelets contain tumor-derived RNA biomarkers. Blood (2011) 118:3680-3. doi: 10.1182/blood-2011-03-344408

67. Leon SA, Shapiro B, Sklaroff DM, Yaros MJ. Free DNA in the Serum of Cancer Patients and the Effect of Therapy. Cancer Res (1977) 37:646-50.

68. Diaz LA, Bardelli A. Liquid biopsies: Genotyping circulating tumor DNA. J Clin Oncol (2014) 32:579-86. doi: 10.1200/JCO.2012.45.2011

69. Abbosh C, Birkbak NJ, Wilson GA, Jamal-Hanjani M, Constantin T, Salari R, et al. Phylogenetic ctDNA analysis depicts early-stage lung cancer evolution. Nature (2017) 545:446-51. doi: 10.1038/nature22364

70. Fiala C, Diamandis EP. Utility of circulating tumor DNA in cancer diagnostics with emphasis on early detection. BMC Med (2018) 16:166. doi: 10.1186/s12916-018-1157-9

71. Casoni GL, Ulivi P, Mercatali L, Chilosi M, Tomassetti S, Romagnoli M, et al. Increased Levels of Free Circulating Dna in Patients with Idiopathic Pulmonary Fibrosis. Int J Biol Markers (2010) 25:229-35. doi: 10.5301/ JBM.2010.6115

72. Chang CP-Y, Chia R-H, Wu T-L, Tsao K-C, Sun C-F, Wu JT. Elevated cellfree serum DNA detected in patients with myocardial infarction. Clin Chim Acta (2003) 327:95-101. doi: 10.1016/S0009-8981(02)00337-6

73. Rainer TH, Lam NYL. Circulating Nucleic Acids and Critical Illness. Ann N Y Acad Sci (2006) 1075:271-7. doi: 10.1196/annals.1368.035

74. Mouliere F, Chandrananda D, Piskorz AM, Moore EK, Morris J, Ahlborn LB, et al. Enhanced detection of circulating tumor DNA by fragment size analysis. Sci Transl Med (2018) 10:eaat4921. doi: 10.1126/scitranslmed. aat 4921

75. Gagan J, Van Allen EM. Next-generation sequencing to guide cancer therapy. Genome Med (2015) 7:80. doi: 10.1186/s13073-015-0203-x

76. Schwaederlé MC, Patel SP, Husain H, Ikeda M, Lanman RB, Banks KC, et al. Utility of Genomic Assessment of Blood-Derived Circulating Tumor DNA (ctDNA) in Patients with Advanced Lung Adenocarcinoma. Clin Cancer Res (2017) 23:5101-11. doi: 10.1158/1078-0432.CCR-16-2497

77. Chang F, Li MM. Clinical application of amplicon-based next-generation sequencing in cancer. Cancer Genet (2013) 206:413-9. doi: 10.1016/ j.cancergen.2013.10.003

78. Remon J, Caramella C, Jovelet C, Lacroix L, Lawson A, Smalley S, et al. Osimertinib benefit inEGFR-mutant NSCLC patients withT790M-mutation detected by circulating tumour DNA. Ann Oncol (2017) 28:784-90. doi: 10.1093/annonc/mdx017

79. Guibert N, Pradines A, Favre G, Mazieres J. Current and future applications of liquid biopsy in nonsmall cell lung cancer from early to advanced stages. Eur Respir Rev (2020) 29:190052. doi: 10.1183/16000617.0052-2019

80. Sozzi G, Conte D, Mariani L, Lo Vullo S, Roz L, Lombardo C, et al. Analysis of Circulating Tumor DNA in Plasma at Diagnosis and during Follow-Up of Lung Cancer Patients. Cancer Res (2001) 61:4675-8.

81. Sozzi G, Conte D, Leon M, Cirincione R, Roz L, Ratcliffe C, et al. Quantification of Free Circulating DNA As a Diagnostic Marker in Lung Cancer. J Clin Oncol (2003) 21:3902-8. doi: 10.1200/JCO.2003.02.006

82. Gautschi O, Bigosch C, Huegli B, Jermann M, Marx A, Chassé E, et al. Circulating Deoxyribonucleic Acid As Prognostic Marker in Non-SmallCell Lung Cancer Patients Undergoing Chemotherapy. J Clin Oncol (2004) 22:4157-64. doi: 10.1200/JCO.2004.11.123

83. Herrera LJ, Raja S, Gooding WE, El-Hefnawy T, Kelly L, Luketich JD, et al. Quantitative Analysis of Circulating Plasma DNA as a Tumor Marker in Thoracic Malignancies. Clin Chem (2005) 51:113-8. doi: 10.1373/ clinchem.2004.039263

84. Ludovini V, Pistola L, Gregorc V, Floriani I, Rulli E, Piattoni S, et al. Microsatellite Alterations, and p53 Tumor Mutations Are Associated with Disease-Free Survival in Radically Resected Non-small Cell Lung Cancer Patients: A Study of the Perugia Multidisciplinary Team for Thoracic Oncology. J Thorac Oncol (2008) 3:365-73. doi: 10.1097/JTO. $0 \mathrm{~b} 013 \mathrm{e} 318168 \mathrm{c} 7 \mathrm{~d} 0$

85. Szpechcinski A, Chorostowska-Wynimko J, Struniawski R, Kupis W, Rudzinski P, Langfort R, et al. Cell-free DNA levels in plasma of patients with non-small-cell lung cancer and inflammatory lung disease. Br J Cancer (2015) 113:476-83. doi: 10.1038/bjc.2015.225

86. Szpechcinski A, Rudzinski P, Kupis W, Langfort R, Orlowski T, Chorostowska-Wynimko J. Plasma cell-free DNA levels and integrity in patients with chest radiological findings: NSCLC versus benign lung nodules. Cancer Lett (2016) 374:202-207. doi: 10.1016/j.canlet.2016.02.002

87. Sozzi G, Roz L, Conte D, Mariani L, Andriani F, Lo Vullo S, et al. Plasma DNA quantification in lung cancer computed tomography screening: fiveyear results of a prospective study. Am J Respir Crit Care Med (2009) 179:6974. doi: $10.1164 / \mathrm{rccm} \cdot 200807-1068 \mathrm{oc}$

88. Paci M, Maramotti S, Bellesia E, Formisano D, Albertazzi L, Ricchetti T, et al. Circulating plasma DNA as diagnostic biomarker in non-small cell lung cancer. Lung Cancer (2009) 64:92-7. doi: 10.1016/j.lungcan.2008.07.012

89. Yoon K-A, Park S, Lee SH, Kim JH, Lee JS. Comparison of circulating plasma DNA levels between lung cancer patients and healthy controls. J Mol Diagn (2009) 11:182-5. doi: 10.2353/jmoldx.2009.080098

90. van der Drift MA, Hol BEA, Klaassen CHW, Prinsen CFM, van Aarssen YAWG, Donders R, et al. Circulating DNA is a non-invasive prognostic factor for survival in non-small cell lung cancer. Lung Cancer (2010) 68:2837. doi: 10.1016/j.lungcan.2009.06.021

91. Catarino R, Coelho A, Araújo A, Gomes M, Nogueira A, Lopes C, et al. Circulating DNA: Diagnostic Tool and Predictive Marker for Overall Survival of NSCLC Patients. PloS One (2012) 7:1-8. doi: 10.1371/ journal.pone.0038559

92. Zhao X, Han R-B, Zhao J, Wang J, Yang F, Zhong W, et al. Comparison of Epidermal Growth Factor Receptor Mutation Statuses in Tissue and Plasma in Stage I-IV Non-Small Cell Lung Cancer Patients. Respiration (2013) 85:119-25. doi: 10.1159/000338790

93. Jing C-W, Wang Z, Cao H-X, Ma R, Wu J-Z. High resolution melting analysis for epidermal growth factor receptor mutations in formalin-fixed paraffin-embedded tissue and plasma free DNA from non-small cell lung cancer patients. Asian Pac J Cancer Prev (2014) 14:6619-23. doi: 10.7314/ APJCP.2013.14.11.6619

94. Uchida J, Kato K, Kukita Y, Kumagai T, Nishino K, Daga H, et al. Diagnostic Accuracy of Noninvasive Genotyping of EGFR in Lung Cancer Patients by Deep Sequencing of Plasma Cell-Free DNA. Clin Chem (2015) 61:1191-6. doi: 10.1373/clinchem.2015.241414

95. Fernandez-Cuesta L, Perdomo S, Avogbe PH, Leblay N, Delhomme TM, Gaborieau V, et al. Identification of Circulating Tumor DNA for the Early Detection of Small-cell Lung Cancer. EBioMedicine (2016) 10:117-23. doi: 10.1016/j.ebiom.2016.06.032

96. Wan Y, Liu B, Lei H, Zhang B, Wang Y, Huang H, et al. Nanoscale extracellular vesicle-derived DNA is superior to circulating cell-free DNA for mutation detection in early-stage non-small-cell lung cancer. Ann Oncol (2018) 29:2379-83. doi: 10.1093/annonc/mdy458

97. Wei F, Strom CM, Cheng J, Lin C-C, Hsu C-Y, Soo Hoo GW, et al. Electric Field-Induced Release and Measurement Liquid Biopsy for Noninvasive Early Lung Cancer Assessment. J Mol Diagnostics (2018) 20:738-42. doi: 10.1016/j.jmoldx.2018.06.008

98. Newman AM, Bratman SV, To J, Wynne JF, Eclov NCW, Modlin LA, et al. An ultrasensitive method for quantitating circulating tumor DNA with broad patient coverage. Nat Med (2014) 20:548-54. doi: 10.1038/ nm.3519

99. Guo N, Lou F, Ma Y, Li J, Yang B, Chen W, et al. Circulating tumor DNA detection in lung cancer patients before and after surgery. Sci Rep (2016) 6:33519. doi: 10.1038/srep33519

100. Chen K-Z, Lou F, Yang F, Zhang J-B, Ye H, Chen W, et al. Circulating Tumor DNA Detection in Early-Stage Non-Small Cell Lung Cancer Patients by Targeted Sequencing. Sci Rep (2016) 6:31985. doi: 10.1038/srep31985

101. Cohen JD, Li L, Wang Y, Thoburn C, Afsari B, Danilova L, et al. Detection and localization of surgically resectable cancers with a multi-analyte blood test. Science (80-) (2018) 359:926-30. doi: 10.1126/science.aar3247

102. Ye M, Li S, Huang W, Wang C, Liu L, Liu J, et al. Comprehensive targeted super-deep next generation sequencing enhances differential diagnosis of solitary pulmonary nodules. J Thorac Dis (2018) 10:S820-9. doi: 10.21037/ jtd.2018.04.09

103. Peng M, Xie Y, Li X, Qian Y, Tu X, Yao X, et al. Resectable lung lesions malignancy assessment and cancer detection by ultra-deep sequencing of targeted gene mutations in plasma cell-free DNA. J Med Genet (2019) 56:647-53. doi: 10.1136/jmedgenet-2018-105825

104. Tailor TD, Rao X, Campa MJ, Wang J, Gregory SG, Patz EFJr. Whole Exome Sequencing of Cell-Free DNA for Early Lung Cancer: A Pilot Study to 
Differentiate Benign From Malignant CT-Detected Pulmonary Lesions. Front Oncol (2019) 9:317. doi: 10.3389/fonc.2019.00317

105. Leung M, Freidin MB, Freydina DV, Von Crease C, De Sousa P, Barbosa MT, et al. Blood-based circulating tumor DNA mutations as a diagnostic and prognostic biomarker for lung cancer. Cancer (2020) 126:1804-9. doi: $10.1002 / \mathrm{cncr} .32699$

106. Wang Y, Yu Z, Wang T, Zhang J, Hong L, Chen L. Identification of epigenetic aberrant promoter methylation of RASSF1A in serum DNA and its clinicopathological significance in lung cancer. Lung Cancer (2007) 56:289-94. doi: 10.1016/j.lungcan.2006.12.007

107. Schmidt B, Liebenberg V, Dietrich D, Schlegel T, Kneip C, Seegebarth A, et al. SHOX2 DNA Methylation is a Biomarker for the diagnosis of lung cancer based on bronchial aspirates. BMC Cancer (2010) 10:600. doi: 10.1186/1471-2407-10-600

108. Kneip C, Schmidt B, Seegebarth A, Weickmann S, Fleischhacker M, Liebenberg V, et al. SHOX2 DNA Methylation Is a Biomarker for the Diagnosis of Lung Cancer in Plasma. J Thorac Oncol (2011) 6:1632-8. doi: 10.1097/JTO.0b013e318220ef9a

109. Hwang S-H, Kim KU, Kim J-E, Kim H-H, Lee MK, Lee CH, et al. Detection of HOXA9 gene methylation in tumor tissues and induced sputum samples from primary lung cancer patients. Clin Chem Lab Med (2011) 49:699-704. doi: 10.1515/CCLM.2011.108

110. Dietrich D, Kneip C, Raji O, Liloglou T, Seegebarth A, Schlegel T, et al. Performance evaluation of the DNA methylation biomarker SHOX2 for the aid in diagnosis of lung cancer based on the analysis of bronchial aspirates. Int J Oncol (2012) 40:825-32. doi: 10.3892/ijo.2011.1264

111. Ponomaryova AA, Rykova EY, Cherdyntseva NV, Skvortsova TE, Dobrodeev AY, Zav'yalov AA, et al. Potentialities of aberrantly methylated circulating DNA for diagnostics and post-treatment follow-up of lung cancer patients. Lung Cancer (2013) 81:397-403. doi: 10.1016/j.lungcan. 2013.05.016

112. Powrózek T, Krawczyk P, Kucharczyk T, Milanowski J. Septin 9 promoter region methylation in free circulating DNA-potential role in noninvasive diagnosis of lung cancer: preliminary report. Med Oncol (2014) 31:917. doi: 10.1007/s12032-014-0917-4

113. Konecny M, Markus J, Waczulikova I, Dolesova L, Kozlova R, Repiska V, et al. The value of SHOX2 methylation test in peripheral blood samples used for the differential diagnosis of lung cancer and other lung disorders. Neoplasma (2016) 63:246-53. doi: 10.4149/210_150419N208

114. Powrózek T, Krawczyk P, Nicoś M, Kuźnar-Kamińska B, Batura-Gabryel H, Milanowski J. Methylation of the DCLK1 promoter region in circulating free DNA and its prognostic value in lung cancer patients. Clin Transl Oncol (2016) 18:398-404. doi: 10.1007/s12094-015-1382-z

115. Ren M, Wang C, Sheng D, Shi Y, Jin M, Xu S. Methylation analysis of SHOX2 and RASSF1A in bronchoalveolar lavage fluid for early lung cancer diagnosis. Ann Diagn Pathol (2017) 27:57-61. doi: 10.1016/j.anndiagpath. 2017.01.007

116. Nunes SP, Diniz F, Moreira-Barbosa C, Constâncio V, Silva AV, Oliveira J, et al. Subtyping Lung Cancer Using DNA Methylation in Liquid Biopsies. J Clin Med (2019) 8:1-14. doi: 10.3390/jcm8091500

117. Fujiwara K, Fujimoto N, Tabata M, Nishii K, Matsuo K, Hotta K, et al. Identification of Epigenetic Aberrant Promoter Methylation in Serum DNA Is Useful for Early Detection of Lung Cancer. Clin Cancer Res (2005) 11:1219-25.

118. Hsu H-S, Chen T-P, Hung C-H, Wen C-K, Lin R-K, Lee H-C, et al. Characterization of a multiple epigenetic marker panel for lung cancer detection and risk assessment in plasma. Cancer (2007) 110:2019-26. doi: $10.1002 /$ cncr.23001

119. Zhang Y, Wang R, Song H, Huang G, Yi J, Zheng Y, et al. Methylation of multiple genes as a candidate biomarker in non-small cell lung cancer. Cancer Lett (2011) 303:21-8. doi: 10.1016/j.canlet.2010.12.011

120. Begum S, Brait M, Dasgupta S, Ostrow KL, Zahurak M, Carvalho AL, et al. An epigenetic marker panel for detection of lung cancer using cell-free serum DNA. Clin Cancer Res (2011) 17:4494-503. doi: 10.1158/1078-0432. CCR-10-3436

121. Nikolaidis G, Raji OY, Markopoulou S, Gosney JR, Bryan J, Warburton C, et al. DNA methylation biomarkers offer improved diagnostic efficiency in lung cancer. Cancer Res (2012) 72:5692-701. doi: 10.1158/0008-5472.can-12-2309
122. Diaz-Lagares A, Mendez-Gonzalez J, Hervas D, Saigi M, Pajares MJ, Garcia D, et al. A Novel Epigenetic Signature for Early Diagnosis in Lung Cancer. Clin Cancer Res (2016) 22:3361-71. doi: 10.1158/1078-0432.CCR-15-2346

123. Ma Y, Bai Y, Mao H, Hong Q, Yang D, Zhang H, et al. A panel of promoter methylation markers for invasive and noninvasive early detection of NSCLC using a quantum dots-based FRET approach. Biosens Bioelectron (2016) 85:641-8. doi: 10.1016/j.bios.2016.05.067

124. Hulbert A, Jusue Torres I, Stark A, Chen C, Rodgers K, Lee B, et al. Early Detection of Lung Cancer using DNA Promoter Hypermethylation in Plasma and Sputum. Clin Cancer Res (2016) 23:clincanres.1371.2016. doi: 10.1158/1078-0432.CCR-16-1371

125. Ooki A, Maleki Z, Tsay J-CJ, Goparaju C, Brait M, Turaga N, et al. A Panel of Novel Detection and Prognostic Methylated DNA Markers in Primary Non-Small Cell Lung Cancer and Serum DNA. Clin Cancer Res (2017) 23:7141-52. doi: 10.1158/1078-0432.ccr-17-1222

126. Hubers AJ, Heideman DAM, Duin S, Witte BI, de Koning HJ, Groen HJM, et al. DNA hypermethylation analysis in sputum of asymptomatic subjects at risk for lung cancer participating in the NELSON trial: argument for maximum screening interval of 2 years. J Clin Pathol (2017) 70:250-4. doi: 10.1136/jclinpath-2016-203734

127. Liang W, Zhao Y, Huang W, Gao Y, Xu W, Tao J, et al. Non-invasive diagnosis of early-stage lung cancer using high-throughput targeted DNA methylation sequencing of circulating tumor DNA (ctDNA). Theranostics (2019) 9:2056-70. doi: 10.7150/thno.28119

128. Balgkouranidou I, Liloglou T, Lianidou ES. Lung cancer epigenetics: emerging biomarkers. Biomark Med (2013) 7:49-58. doi: 10.2217/ bmm.12.111

129. Yu L, Liu H, Yan M, Yang J, Long F, Muneoka K, et al. Shox2 is required for chondrocyte proliferation and maturation in proximal limb skeleton. Dev Biol (2007) 306:549-59. doi: 10.1016/j.ydbio.2007.03.518

130. Blaschke RJ, Monaghan AP, Schiller S, Schechinger B, Rao E, Padilla-Nash $\mathrm{H}$, et al. SHOT, a SHOX-related homeobox gene, is implicated in craniofacial, brain, heart, and limb development. Proc Natl Acad Sci USA (1998) 95:2406-11. doi: 10.1073/pnas.95.5.2406

131. de Wit S, Rossi E, Weber S, Tamminga M, Manicone M, Swennenhuis JF, et al. Single tube liquid biopsy for advanced non-small cell lung cancer. Int $J$ Cancer (2019) 144:3127-37. doi: 10.1002/ijc.32056

132. Wang J, Wang K, Xu J, Huang J, Zhang T. Prognostic significance of circulating tumor cells in non-small-cell lung cancer patients: a meta-analysis. PloS One (2013) 8:e78070-0. doi: 10.1371/journal.pone.0078070

133. Hamilton G, Rath B. Detection of circulating tumor cells in non-small cell lung cancer. J Thorac Dis (2016) 8:1024-8. doi: 10.21037/jtd.2016.03.86

134. Allard WJ, Matera J, Miller MC, Repollet M, Connelly MC, Rao C, et al. Tumor cells circulate in the peripheral blood of all major carcinomas but not in healthy subjects or patients with nonmalignant diseases. Clin Cancer Res (2005) 10:6897-904. doi: 10.1158/1078-0432.CCR-04-0378

135. Tanaka F, Yoneda K, Kondo N, Hashimoto M, Takuwa T, Matsumoto S, et al. Circulating Tumor Cell as a Diagnostic Marker in Primary Lung Cancer. Clin Cancer Res (2009) 15:6980-6. doi: 10.1158/1078-0432.CCR-09-1095

136. Hofman V, Bonnetaud C, Ilie MI, Vielh P, Vignaud JM, Fléjou JF, et al. Preoperative Circulating Tumor Cell Detection Using the Isolation by Size of Epithelial Tumor Cell Method for Patients with Lung Cancer Is a New Prognostic Biomarker. Clin Cancer Res (2011) 17:827-35. doi: 10.1158/10780432.CCR-10-0445

137. Hofman V, Ilie MI, Long E, Selva E, Bonnetaud C, Molina T, et al. Detection of circulating tumor cells as a prognostic factor in patients undergoing radical surgery for non-small-cell lung carcinoma: comparison of the efficacy of the CellSearch Assay ${ }^{\mathrm{TM}}$ and the isolation by size of epithelial tumor cell method. Int J Cancer (2011) 129:1651-60. doi: 10.1002/ijc.25819

138. Hofman V, Long E, Ilie M, Bonnetaud C, Vignaud JM, Fléjou JF, et al. Morphological analysis of circulating tumour cells in patients undergoing surgery for non-small cell lung carcinoma using the isolation by size of epithelial tumour cell (ISET) method. Cytopathology (2012) 23:30-8. doi: 10.1111/j.1365-2303.2010.00835.x

139. Ilie M, Hofman V, Long-Mira E, Selva E, Vignaud J-M, Padovani B, et al. "Sentinel" circulating tumor cells allow early diagnosis of lung cancer in patients with chronic obstructive pulmonary disease. PloS One (2014) 9:e111597. doi: 10.1371/journal.pone.0111597 
140. Dorsey JF, Kao GD, MacArthur KM, Ju M, Steinmetz D, Wileyto EP, et al. Simone 2nd CBTracking viable circulating tumor cells (CTCs) in the peripheral blood of non-small cell lung cancer (NSCLC) patients undergoing definitive radiation therapy: pilot study results. Cancer (2015) 121:139-49. doi: 10.1002/cncr.28975

141. Fiorelli A, Accardo M, Carelli E, Angioletti D, Santini M, Di Domenico M. Circulating Tumor Cells in Diagnosing Lung Cancer: Clinical and Morphologic Analysis. Ann Thorac Surg (2015) 99:1899-905. doi: 10.1016/ j.athoracsur.2014.11.049

142. Chen X, Zhou F, Li X, Yang G, Zhang L, Ren S, et al. Folate ReceptorPositive Circulating Tumor Cell Detected by LT-PCR-Based Method as a Diagnostic Biomarker for Non-Small-Cell Lung Cancer. J Thorac Oncol (2015) 10:1163-71. doi: 10.1097/JTO.0000000000000606

143. Xu Y, Liu B, Ding F, Zhou X, Tu P, Yu B, et al. Circulating tumor cell detection: A direct comparison between negative and unbiased enrichment in lung cancer. Oncol Lett (2017) 13:4882-6. doi: 10.3892/ol.2017.6046

144. Xue Y, Cong W, Xie S, Shu J, Feng G, Gao H. Folate-receptor-positive circulating tumor cells as an efficacious biomarker for the diagnosis of small pulmonary nodules. J Cancer Res Ther (2018) 14:1620-6. doi: 10.4103/ jcrt.JCRT_905_17

145. Frick MA, Feigenberg SJ, Jean-Baptiste SR, Aguarin LA, Mendes A, Chinniah C, et al. Circulating tumor cells are associated with recurrent disease in patients with early stage non-small cell lung cancer treated with stereotactic body radiation therapy. Clin Cancer Res (2020) 26:clincanres.2158.2019. doi: 10.1158/1078-0432.CCR-19-2158

146. He Y, Shi J, Shi G, Xu X, Liu Q, Liu C, et al. Using the New CellCollector to Capture Circulating Tumor Cells from Blood in Different Groups of Pulmonary Disease: A Cohort Study. Sci Rep (2017) 7:9542. doi: 10.1038/ s41598-017-09284-0

147. Duan G-C, Zhang X-P, Wang H-E, Wang Z-K, Zhang H, Yu L, et al. Circulating Tumor Cells as a Screening and Diagnostic Marker for EarlyStage Non-Small Cell Lung Cancer. Onco Targets Ther (2020) 13:1931-9. doi: 10.2147/OTT.S241956

148. He Y, Shi J, Schmidt B, Liu Q, Shi G, Xu X, et al. Circulating Tumor Cells as a Biomarker to Assist Molecular Diagnosis for Early Stage Non-Small Cell Lung Cancer. Cancer Manag Res (2020) 12:841-54. doi: 10.2147/CMAR.S240773

149. Hofman VJ, Ilie M, Hofman PM. Detection and characterization of circulating tumor cells in lung cancer: Why and how? Cancer Cytopathol (2016) 124:380-7. doi: 10.1002/cncy.21651

150. Tamminga M, de Wit S, Schuuring E, Timens W, Terstappen LWMM, Hiltermann TJN, et al. Circulating tumor cells in lung cancer are prognostic and predictive for worse tumor response in both targeted- and chemotherapy. Transl Lung Cancer Res Vol 8, No 6 (December 2019). Transl Lung Cancer Res (2019) 8(6):854-61. doi: 10.21037/tlcr.2019.11.06

151. Lindsay CR, Blackhall FH, Carmel A, Fernandez-Gutierrez F, Gazzaniga P, Groen HJM, et al. EPAC-lung: pooled analysis of circulating tumour cells in advanced non-small cell lung cancer. Eur J Cancer (2019) 117:60-8. doi: 10.1016/j.ejca.2019.04.019

152. Liu Z, Fusi A, Klopocki E, Schmittel A, Tinhofer I, Nonnenmacher A, et al. Negative enrichment by immunomagnetic nanobeads for unbiased characterization of circulating tumor cells from peripheral blood of cancer patients. J Transl Med (2011) 9:70. doi: 10.1186/1479-5876-9-70

153. Ozkumur E, Shah AM, Ciciliano JC, Emmink BL, Miyamoto DT, Brachtel E, et al. Inertial focusing for tumor antigen-dependent and -independent sorting of rare circulating tumor cells. Sci Transl Med (2013) 5:179ra47. doi: $10.1126 /$ scitranslmed.3005616

154. He W, Kularatne SA, Kalli KR, Prendergast FG, Amato RJ, Klee GG, et al. Quantitation of circulating tumor cells in blood samples from ovarian and prostate cancer patients using tumor-specific fluorescent ligands. Int $J$ Cancer (2008) 123:1968-73. doi: 10.1002/ijc.23717

155. Parker N, Turk MJ, Westrick E, Lewis JD, Low PS, Leamon CP. Folate receptor expression in carcinomas and normal tissues determined by a quantitative radioligand binding assay. Anal Biochem (2005) 338:284-93. doi: 10.1016/j.ab.2004.12.026

156. Saucedo-Zeni N, Mewes S, Niestroj R, Gasiorowski L, Murawa D, Nowaczyk P, et al. A novel method for the in vivo isolation of circulating tumor cells from peripheral blood of cancer patients using a functionalized and structured medical wire. Int J Oncol (2012) 41:1241-50. doi: 10.3892/ijo.2012.1557
157. Gorges TM, Penkalla N, Schalk T, Joosse SA, Riethdorf S, Tucholski J, et al. Enumeration and Molecular Characterization of Tumor Cells in Lung Cancer Patients Using a Novel In Vivo Device for Capturing Circulating Tumor Cells. Clin Cancer Res (2016) 22:2197-206. doi: 10.1158/10780432.CCR-15-1416

158. Nagrath S, Sequist LV, Maheswaran S, Bell DW, Irimia D, Ulkus L, et al. Isolation of rare circulating tumour cells in cancer patients by microchip technology. Nature (2007) 450:1235-9. doi: 10.1038/nature06385

159. Neves RPL, Ammerlaan W, Andree KC, Bender S, Cayrefourcq L, Driemel C, et al. Proficiency Testing to Assess Technical Performance for CTCProcessing and Detection Methods in CANCER-ID. Clin Chem (2021) 67 (4):631-41. doi: 10.1093/clinchem/hvaa322

160. Mitchell PS, Parkin RK, Kroh EM, Fritz BR, Wyman SK, PogosovaAgadjanyan EL, et al. Circulating microRNAs as stable blood-based markers for cancer detection. Proc Natl Acad Sci (2008) 105:10513-8. doi: 10.1073/pnas.0804549105

161. Chen X, Ba Y, Ma L, Cai X, Yin Y, Wang K, et al. Characterization of microRNAs in serum: a novel class of biomarkers for diagnosis of cancer and other diseases. Cell Res (2008) 18:997-1006. doi: 10.1038/cr.2008.282

162. Xie Y, Todd NW, Liu Z, Zhan M, Fang H, Peng H, et al. Altered miRNA expression in sputum for diagnosis of non-small cell lung cancer. Lung Cancer (2010) 67:170-6. doi: 10.1016/j.lungcan.2009.04.004

163. Yu L, Todd NW, Xing L, Xie Y, Zhang H, Liu Z, et al. Early detection of lung adenocarcinoma in sputum by a panel of microRNA markers. Int $J$ Cancer (2010) 127:2870-8. doi: 10.1002/ijc.25289

164. Shen J, Todd NW, Zhang H, Yu L, Lingxiao X, Mei Y, et al. Plasma microRNAs as potential biomarkers for non-small-cell lung cancer. Lab Investig (2011) 91:579-87. doi: 10.1038/labinvest.2010.194

165. Shen J, Liu Z, Todd NW, Zhang H, Liao J, Yu L, et al. Diagnosis of lung cancer in individuals with solitary pulmonary nodules by plasma microRNA biomarkers. BMC Cancer (2011) 11:374. doi: 10.1186/14712407-11-374

166. Zheng D, Haddadin S, Wang Y, Gu L-Q, Perry MC, Freter CE, et al. Plasma microRNAs as novel biomarkers for early detection of lung cancer. Int J Clin Exp Pathol (2011) 4:575-86.

167. Boeri M, Verri C, Conte D, Roz L, Modena P, Facchinetti F, et al. MicroRNA signatures in tissues and plasma predict development and prognosis of computed tomography detected lung cancer. Proc Natl Acad Sci USA (2011) 108:3713-8. doi: 10.1073/pnas.1100048108

168. Foss KM, Sima C, Ugolini D, Neri M, Allen KE, Weiss GJ. miR-1254 and miR-574-5p: Serum-Based microRNA Biomarkers for Early-Stage Nonsmall Cell Lung Cancer. J Thorac Oncol (2011) 6:482-8. doi: 10.1097/ JTO.0b013e318208c785

169. Bianchi F, Nicassio F, Marzi M, Belloni E, Dall'olio V, Bernard L, et al. A serum circulating miRNA diagnostic test to identify asymptomatic high-risk individuals with early stage lung cancer. EMBO Mol Med (2011) 3:495-503. doi: $10.1002 / \mathrm{emmm} .201100154$

170. Heegaard NHH, Schetter AJ, Welsh JA, Yoneda M, Bowman ED, Harris CC. Circulating micro-RNA expression profiles in early stage nonsmall cell lung cancer. Int J Cancer (2012) 130:1378-86. doi: 10.1002/ijc.26153

171. Sozzi G, Boeri M, Rossi M, Verri C, Suatoni P, Bravi F, et al. Clinical utility of a plasma-based miRNA signature classifier within computed tomography lung cancer screening: a correlative MILD trial study. J Clin Oncol (2014) 32:768-73. doi: 10.1200/JCO.2013.50.4357

172. Shen J, Liao J, Guarnera MA, Fang H, Cai L, Stass SA, et al. Analysis of MicroRNAs in sputum to improve computed tomography for lung cancer diagnosis. J Thorac Oncol (2014) 9:33-40. doi: 10.1097/JTO. 0000000000000025

173. Wang P, Yang D, Zhang H, Wei X, Ma T, Cheng Z, et al. Early Detection of Lung Cancer in Serum by a Panel of MicroRNA Biomarkers. Clin Lung Cancer (2015) 16:313-9.e1. doi: 10.1016/j.cllc.2014.12.006

174. Montani F, Marzi MJ, Dezi F, Dama E, Carletti RM, Bonizzi G, et al. miRTest: A Blood Test for Lung Cancer Early Detection. JNCI J Natl Cancer Inst (2015) 107:1-5. doi: 10.1093/jnci/djv063

175. Xing L, Su J, Guarnera MA, Zhang H, Cai L, Zhou R, et al. Sputum microRNA biomarkers for identifying lung cancer in indeterminate solitary pulmonary nodules. Clin Cancer Res (2015) 21:484-9. doi: 10.1158/1078-0432.CCR-14-1873 
176. Wang C, Ding M, Xia M, Chen S, Van Le A, Soto-Gil R, et al. A Five-miRNA Panel Identified From a Multicentric Case-control Study Serves as a Novel Diagnostic Tool for Ethnically Diverse Non-small-cell Lung Cancer Patients. EBioMedicine (2015) 2:1377-85. doi: 10.1016/j.ebiom.2015.07.034

177. Kim JO, Gazala S, Razzak R, Guo L, Ghosh S, Roa WH, et al. Non-small Cell Lung Cancer Detection Using MicroRNA Expression Profiling of Bronchoalveolar Lavage Fluid and Sputum. Anticancer Res (2015) 35:1873-80.

178. Li W, Wang Y, Zhang Q, Tang L, Liu X, Dai Y, et al. MicroRNA-486 as a Biomarker for Early Diagnosis and Recurrence of Non-Small Cell Lung Cancer. PloS One (2015) 10:e0134220. doi: 10.1371/journal.pone.0134220

179. Fan L, Qi H, Teng J, Su B, Chen H, Wang C, et al. Identification of serum miRNAs by nano-quantum dots microarray as diagnostic biomarkers for early detection of non-small cell lung cancer. Tumour Biol (2016) 37:777784. doi: 10.1007/s13277-015-4608-3

180. Razzak R, Bédard ELR, Kim JO, Gazala S, Guo L, Ghosh S, et al. MicroRNA expression profiling of sputum for the detection of early and locally advanced non-small-cell lung cancer: a prospective case-control study. Curr Oncol (2016) 23:e86-94. doi: 10.3747/co.23.2830

181. Bagheri A, Khorram Khorshid HR, Mowla SJ, Mohebbi HA, Mohammadian A, Yaseri M, et al. Altered miR-223 Expression in Sputum for Diagnosis of Non-Small Cell Lung Cancer. Avicenna J Med Biotechnol (2017) 9:189-95.

182. Leng Q, Lin $\mathrm{Y}$, Jiang F, Lee C-J, Zhan M, Fang H, et al. A plasma miRNA signature for lung cancer early detection. Oncotarget (2017) 8:111902-11. doi: 10.18632/oncotarget.22950

183. Lu S, Kong H, Hou Y, Ge D, Huang W, Ou J, et al. Two plasma microRNA panels for diagnosis and subtype discrimination of lung cancer. Lung Cancer (2018) 123:44-51. doi: 10.1016/j.lungcan.2018.06.027

184. Abu-Duhier FM, Javid J, Sughayer MA, Mir R, Albalawi T, Alauddin MS. Clinical Significance of Circulatory miRNA-21 as an Efficient Non-Invasive Biomarker for the Screening of Lung Cancer Patients. Asian Pac J Cancer Prev (2018) 19:2607-11. doi: 10.22034/APJCP.2018.19.9.2607

185. Xi K-X, Zhang X-W, Yu X-Y, Wang W-D, Xi K-X, Chen Y-Q, et al. The role of plasma miRNAs in the diagnosis of pulmonary nodules. $J$ Thorac Dis (2018) 10:4032-41. doi: 10.21037/jtd.2018.06.106

186. Li J, Fang H, Jiang F, Ning Y. External validation of a panel of plasma microRNA biomarkers for lung cancer. Biomark Med (2019) 13:1557-64. doi: $10.2217 / \mathrm{bmm}-2019-0213$

187. Liang L-B, Zhu W-J, Chen X-M, Luo F-M. Plasma miR-30a-5p as an early novel noninvasive diagnostic and prognostic biomarker for lung cancer. Futur Oncol (2019) 15:3711-21. doi: 10.2217/fon-2019-0393

188. Xi K, Wang W, Wen Y, Chen Y, Zhang X, Wu Y, et al. Combining Plasma miRNAs and Computed Tomography Features to Differentiate the Nature of Pulmonary Nodules. Front Oncol (2019) 9:975. doi: 10.3389/fonc.2019.00975

189. Liao J, Shen J, Leng Q, Qin M, Zhan M, Jiang F. MicroRNA-based biomarkers for diagnosis of non-small cell lung cancer (NSCLC). Thorac Cancer (2020) 11:762-8. doi: 10.1111/1759-7714.13337

190. Mensah M, Borzi C, Verri C, Suatoni P, Conte D, Pastorino U, et al. MicroRNA Based Liquid Biopsy: The Experience of the Plasma miRNA Signature Classifier (MSC) for Lung Cancer Screening. J Vis Exp (2017) 190:56326. doi: 10.3791/56326

191. Pastorino U, Boeri M, Sestini S, Sabia F, Silva M, Suatoni P, et al. PL02.04 Blood MicroRNA and LDCT Reduce Unnecessary LDCT Repeats in Lung Cancer Screening: Results of Prospective BioMILD Trial. J Thorac Oncol (2019) 14:S5-6. doi: 10.1016/j.jtho.2019.08.057

192. Yang Y, Hu Z, Zhou Y, Zhao G, Lei Y, Li G, et al. The clinical use of circulating microRNAs as non-invasive diagnostic biomarkers for lung cancers. Oncotarget (2017) 8:90197-214. doi: 10.18632/oncotarget.21644

193. Yu H, Guan Z, Cuk K, Brenner H, Zhang Y. Circulating microRNA biomarkers for lung cancer detection in Western populations. Cancer Med (2018) 7:4849-62. doi: 10.1002/cam4.1782

194. Thunnissen FBJM. Sputum examination for early detection of lung cancer. J Clin Pathol (2003) 56:805-10. doi: 10.1136/jcp.56.11.805

195. Saccomanno G, Archer VE, Auerbach O, Saunders RP, Brennan LM. Development of carcinoma of the lung as reflected in exfoliated cells. Cancer (1974) 33:256-70. doi: 10.1002/1097-0142(197401)33:1<256::AIDCNCR2820330139>3.0.CO;2-G
196. Xing L, Todd NW, Yu L, Fang H, Jiang F. Early detection of squamous cell lung cancer in sputum by a panel of microRNA markers. Mod Pathol (2010) 23:1157-64. doi: 10.1038/modpathol.2010.111

197. Rabinowits G, Gerçel-Taylor C, Day JM, Taylor DD, Kloecker GH. Exosomal microRNA: A diagnostic marker for lung cancer. Clin Lung Cancer (2009) 10:42-6. doi: 10.3816/CLC.2009.n.006

198. Cazzoli R, Buttitta F, Di Nicola M, Malatesta S, Marchetti A, Rom WN, et al. microRNAs Derived from Circulating Exosomes as Noninvasive Biomarkers for Screening and Diagnosing Lung Cancer. J Thorac Oncol (2013) 8:115662. doi: 10.1097/JTO.0b013e318299ac32

199. Zhou X, Wen W, Shan X, Zhu W, Xu J, Guo R, et al. A six-microRNA panel in plasma was identified as a potential biomarker for lung adenocarcinoma diagnosis. Oncotarget (2017) 8:6513-25. doi: 10.18632/oncotarget.14311

200. Jin X, Chen Y, Chen H, Fei S, Chen D, Cai X, et al. Evaluation of TumorDerived Exosomal miRNA as Potential Diagnostic Biomarkers for EarlyStage Non-Small Cell Lung Cancer Using Next-Generation Sequencing. Clin Cancer Res (2017) 23:5311-9. doi: 10.1158/1078-0432.CCR-17-0577

201. Lin J, Wang Y, Zou Y-Q, Chen X, Huang B, Liu J, et al. Differential miRNA expression in pleural effusions derived from extracellular vesicles of patients with lung cancer, pulmonary tuberculosis, or pneumonia. Tumor Biol (2016) 37:15835-45. doi: 10.1007/s13277-016-5410-6

202. Krug AK, Enderle D, Karlovich C, Priewasser T, Bentink S, Spiel A, et al. Improved EGFR mutation detection using combined exosomal RNA and circulating tumor DNA in NSCLC patient plasma. Ann Oncol Off J Eur Soc Med Oncol (2018) 29:700-6. doi: 10.1093/annonc/mdx765

203. Thakur BK, Zhang H, Becker A, Matei I, Huang Y, Costa-Silva B, et al. Double-stranded DNA in exosomes: a novel biomarker in cancer detection. Cell Res (2014) 24:766-9. doi: 10.1038/cr.2014.44

204. Huang S, Li Y, Zhang J, Rong J, Ye S. Epidermal Growth Factor ReceptorContaining Exosomes Induce Tumor-Specific Regulatory T Cells. Cancer Invest (2013) 31:330-5. doi: 10.3109/07357907.2013.789905

205. Clark DJ, Fondrie WE, Yang A, Mao L. Triple SILAC quantitative proteomic analysis reveals differential abundance of cell signaling proteins between normal and lung cancer-derived exosomes. J Proteomics (2016) 133:161-9. doi: 10.1016/j.jprot.2015.12.023

206. Sandfeld-Paulsen B, Jakobsen KR, Bæk R, Folkersen BH, Rasmussen TR, Meldgaard P, et al. Exosomal Proteins as Diagnostic Biomarkers in Lung Cancer. J Thorac Oncol (2016) 11:1701-10. doi: 10.1016/ j.jtho.2016.05.034

207. Jakobsen KR, Paulsen BS, Bæk R, Varming K, Sorensen BS, Jørgensen MM. Exosomal proteins as potential diagnostic markers in advanced non-small cell lung carcinoma. J Extracell vesicles (2015) 4:26659. doi: 10.3402/ jev.v4.26659

208. Zhang Y, Zhang Y, Yin Y, Li S. Detection of circulating exosomal miR-17-5p serves as a novel non-invasive diagnostic marker for non-small cell lung cancer patients. Pathol - Res Pract (2019) 215:152466. doi: 10.1016/ j.prp.2019.152466

209. Jarry J, Schadendorf D, Greenwood C, Spatz A, van Kempen LC. The validity of circulating microRNAs in oncology: Five years of challenges and contradictions. Mol Oncol (2014) 8:819-29. doi: 10.1016/j.molonc.2014.02.009

210. Best MG, Sol N, Kooi I, Tannous J, Westerman BA, Rustenburg F, et al. RNA-Seq of Tumor-Educated Platelets Enables Blood-Based Pan-Cancer, Multiclass, and Molecular Pathway Cancer Diagnostics. Cancer Cell (2015) 28:666-76. doi: 10.1016/j.ccell.2015.09.018

211. Nilsson RJA, Karachaliou N, Berenguer J, Gimenez-Capitan A, Schellen P, Teixido C, et al. Rearranged EML4-ALK fusion transcripts sequester in circulating blood platelets and enable blood-based crizotinib response monitoring in non-small-cell lung cancer. Oncotarget (2016) 7:1066-75. doi: 10.18632 /oncotarget.6279

212. Li D, Yang W, Zhang Y, Yang JY, Guan R, Xu D, et al. Genomic analyses based on pulmonary adenocarcinoma in situ reveal early lung cancer signature. BMC Med Genomics (2018) 11:106. doi: 10.1186/s12920-018-0413-3

213. Sheng M, Dong Z, Xie Y. Identification of tumor-educated platelet biomarkers of non-small-cell lung cancer. Onco Targets Ther (2018) 11:8143-51. doi: 10.2147/OTT.S177384

214. Xue L, Xie L, Song X, Song X. [Expression and Significance of ACIN1 mRNA in Platelets of Lung Cancer]. Zhongguo Fei Ai Za Zhi (2018) 21:677-81. doi: 10.3779/j.issn.1009-3419.2018.09.05 
215. Calverley DC, Phang TL, Choudhury QG, Gao B, Oton AB, Weyant MJ, et al. Significant downregulation of platelet gene expression in metastatic lung cancer. Clin Transl Sci (2010) 3:227-32. doi: 10.1111/j.17528062.2010.00226.x

Conflict of Interest: The authors declare that the research was conducted in the absence of any commercial or financial relationships that could be construed as a potential conflict of interest.
Copyright () 2021 Freitas, Sousa, Machado, Serino, Santos, Cruz-Martins, Teixeira, Cunha, Pereira, Oliveira, Costa and Hespanhol. This is an open-access article distributed under the terms of the Creative Commons Attribution License (CC BY). The use, distribution or reproduction in other forums is permitted, provided the original author(s) and the copyright owner(s) are credited and that the original publication in this journal is cited, in accordance with accepted academic practice. No use, distribution or reproduction is permitted which does not comply with these terms. 